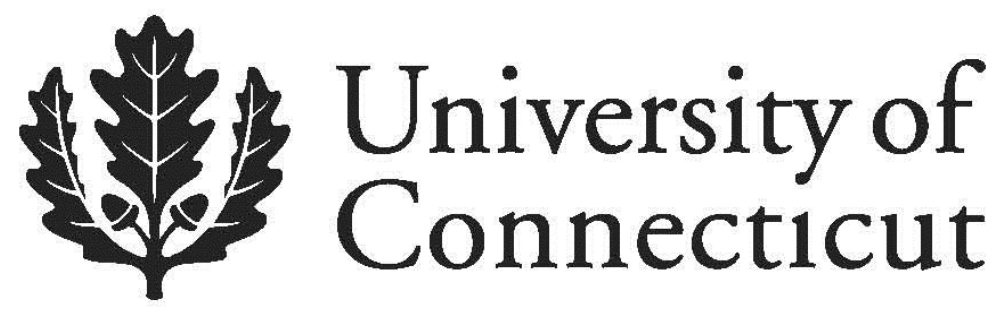

Department of Economics Working Paper Series

\title{
Health Spending and Public Pension: Evidence from Panel Data
}

Yonghong An

Texas A\&M University

Kai Zhao

University of Connecticut

Rhong Zhou

University of Connecticut

Working Paper 2014-27

September 2014

365 Fairfield Way, Unit 1063

Storrs, CT 06269-1063

Phone: (860) 486-3022

Fax: (860) 486-4463

http://www.econ.uconn.edu/

This working paper is indexed on RePEc, http://repec.org 


\title{
Health Spending and Public Pension: Evidence from Panel Data*
}

\author{
Yonghong $\mathrm{An}^{\dagger} \quad$ Kai Zhao ${ }^{\ddagger} \quad$ Rong Zhou ${ }^{\S}$
}

September 2014

\begin{abstract}
This paper empirically investigates the determinants of aggregate health expenditure in a panel of OECD countries from 1980-2005. We differ from most existing studies by testing some new determinants motivated by recent theoretical advances in the literature. We find that a one percentage increase in public pension payments per elderly person leads to approximately a $1 / 3$ percentage increase in aggregate health spending, and this effect is significant and robust across a variety of model specifications. A back of the envelope calculation based on this estimate suggests that the expansion of the public pension program on average accounts for approximately over one fifth of the rise in aggregate health expenditure as a share of GDP in the set of OECD countries during 1980-2005. In addition, we find that the estimated effect of GDP per capita in our model ranges from 0.66 to 0.80 , which is consistent with the results from some recent studies, and thus further reinforces the finding in the literature that health care is not a luxury good. Finally, our results show that the political factors do not significantly affect aggregate health expenditure, though they have been found to be important for understanding public health spending in existing studies.
\end{abstract}

Keywords: Aggregate Health Expenditure, Public Pension, Labor Supply.

JEL Classifications: H51, I1

${ }^{*}$ We thank Jorge Agüero, Resul Cesur, Jason Lindo, Niklas Potrafke, David Simon, and Stephen Ross for their helpful comments or discussions. We are grateful to Niklas Potrafke for sharing the data. All errors remain our own.

${ }^{\dagger}$ Department of Economics, Texas A\&M University, College Station, TX 77843, USA. Email: y.an@tamu.edu.

${ }_{\ddagger}^{\ddagger}$ Department of Economics, The University of Connecticut, Storrs, CT 06269-1063, USA. Tel.: +1 860486 4326. Email: kai.zhao@uconn.edu.

${ }^{\S}$ Department of Economics, The University of Connecticut, Storrs, CT 06269-1063, USA. 


\section{Introduction}

It is well known that aggregate health expenditure in developed countries has risen dramatically over the last several decades. For instance, aggregate health spending as a share of GDP in developed OECD countries was on average only 4\% in 1960 and it jumped to $10 \%$ in 2005 I $^{1}$ Why has health spending risen so much in developed countries? This question has attracted growing attention in the literature $2^{2}$ The conventional explanations for the rise in health spending include income growth, increased health insurance coverage, demographic change, etc. However, previous studies have found that these explanations are either insignificant or quantitatively not enough to explain the dramatic rise in health spending $3^{3}$ As argued in Newhouse (1992), these explanations together only account for a small portion of the rise in health spending, suggesting that a large portion of the rise in health spending still remains unexplained.

Motivated by the large unexplained residual, the recent literature has tried to identify new explanations for the rapid rise in aggregate health spending. $4^{4}$ Among these studies, Zhao (2014) argues that the size of the public pension program may be an important determinant of aggregate health spending because the public pension program redistributes resources to the elderly whose marginal propensity to spend on health care is much higher than the rest of the population 5 Using numerical simulations techniques, he finds that the expansion of public pension in the US can account for over a third of the rise in US aggregate health spending as a share of GDP over the last half century. The main goal of this paper is to empirically test this hypothesis by estimating the determinants of aggregate health spending in a panel of 21 OECD countries over the period 1980-2005 using a linear panel data model. In particular, we include the size of the public pension program (measured by public pension payments per elderly person) into an otherwise standard empirical model for the determinants of aggregate health spending, and we focus on its effect on health spending by exploring a variety of specifications.

Our main finding is that the size of public pension has a positive effect on the aggregate

\footnotetext{
${ }^{1}$ See the 2013 OECD Health data.

${ }^{2}$ Newhouse (1992), Finkelstein (2007), Hall and Jones (2007), CBO (2008), Acemoglu et al. (2013), and among others.

${ }^{3}$ See Newhouse (1992) and CBO (2008) for a review of these studies. ${ }^{4}$ Suen (2006), Hall and Jones (2007), He and Huang (2013), Zhao (2014), etc.

${ }^{5}$ Marginal propensity to spend on health care is defined as follows: how many cents of health spending would be induced by one extra dollar of disposable income. According to Follette and Sheiner (2005), elderly households spend a much larger share of their income on health care than non-elderly households.
} 
health expenditure of the country, and this effect is significant and robust across all the model specifications. Specifically, a one percentage increase in public pension payments per elderly person leads to approximately a $1 / 3$ percentage increase in health spending per capita in our baseline specification. This result suggests that the expansion of public pension may be an important reason why aggregate health spending as a share of GDP has risen so much in developed countries. Using our baseline estimate, a simple back of the envelope calculation suggests that the expansion of public pension in the set of OECD countries can account for approximately one fifth of the rise in aggregate health spending as a share of GDP over 1980-2005.

We did not find consistently significant effects of political variables (electoral motives, government ideology, etc.) on aggregate health expenditure while some recent studies, e.g., Potrafke (2010) and Herwartz and Theilen (2014) documented that political factors are important for understanding public health expenditure. A possible reason that political factors affect public health expenditure but not the aggregate one is that public health expenditure may have a crowding out effect on private health expenditure. For example, Potrafke (2010) finds that private health expenditure is negatively correlated with public health expenditure after the effects of political variables and some other covariates are controlled for. Consequently, private health expenditure may decrease when the public one increase due to electoral motives, etc.

In addition, we find that the estimated effect of GDP per capita (i.e., the main existing explanatory variable) on health spending ranges from 0.66 to 0.80 in our empirical model. These estimates are consistent with the recent results in Acemoglu et al. (2013), where the effect of income on health spending is found to be from $0.7-1.1$ by instrumenting for local area income with time series variation in oil prices interacted with local oil reserves. Thus our results further reinforce the finding in the literature that health care is not a luxury good, and consequently income growth may not be an important cause of the rise in aggregate health spending as a share of GDP 6

It is worth noting that we also extend our empirical analysis to include another new explanatory variable, the aggregate hours worked per working-age person, which is a commonly-used measure for aggregate labor supply in macroeconomics literature. He and Huang (2013) have recently suggested that this variable may be another possible determinant of aggregate health spending. They argue that both leisure time and health care are inputs in the production of

\footnotetext{
${ }^{6}$ See Blomqvist and Carter (1997), Acemoglu et al. (2013) among others.
} 
good health, therefore leisure time is a substitute for spending on health care. According to this theory, aggregate labor supply is expected to have a positive effect on aggregate health spending. In a quantitative dynamic macro model with endogenous health capital, they show that an important reason why Americans spend much more on health care than Europeans is that Americans work much more. Their numerical simulation results suggest that aggregate hours worked per working-age person can be another determinant of aggregate health spending. We also test this hypothesis in our empirical analysis. However, we find that the estimated effect of aggregate hours worked on health spending is small and is insignificant in most model specifications $]^{7}$

This paper is closely related to the literature that uses panel data models to identify the determinants of aggregate health spending among a set of OECD countries (see Gerdtham and Jonsson (2000) for a review of this literature). Most studies in this literature have focused on the main common hypothesis, i.e., the income growth hypothesis. This hypothesis can also be rephrased as the idea that health care is a luxury good so that health spending as a share of GDP increases as income grows. These studies found that the effect of GDP per capita on health spending is significant and the effect is robust, but the estimated income elasticity of health spending is usually less than one or only slightly higher than one, which suggests that income growth may not be the important cause of the rise in health spending as a share of GDP over the last several decades 8 The literature has also studied many other relevant variables, e.g., the share of elderly population and the share of public health spending. However, most of them have been found either insignificant or quantitatively not important. As suggested by Gerdtham and Jonsson (2000) in their review article, this literature needs more macroeconomic theories of health expenditure, and should look for new determinants of aggregate health expenditure. In line with this suggestion, for example, Potrafke (2010) finds election has a significant effect on a government's spending on public health care and and Herwartz and Theilen (2014) reinforce that political factors are important determinants of trends in public health care. We also follow this suggestion seriously. By taking advantage of the recent advance in the macro literature that develops and studies quantitative theories of the macroeconomics of health expenditure, we empirically test several new determinants of aggregate health expenditure, and find that

\footnotetext{
${ }^{7}$ Note that several existing empirical studies have included unemployment rate in their models, which is related to labor supply. However, the unemployment rate is not really a measure of aggregate labor supply because the aggregate labor supply of a country is mainly determined by the labor force participation rate rather than unemployment rate. The variable we use here measures the average hours worked per person in the population, and thus it also captures what fraction of the population participates in the labor force.

${ }^{8}$ For example, Gerdtham et al. (1992b), Blomqvist and Carter (1997).
} 
public pension payments per elderly person is another important determinant of aggregate health spending.

The rest of the paper is organized as follows. We explain our hypothesis in section 2, and describe the data and our empirical strategy in section 3. We present the main empirical results and provide further discussions in section 4 and conclude in section 5 .

\section{The Main Hypothesis}

We hypothesize that an expansion of the public pension program would increase the aggregate health spending of the country after controlling for other covariates. As argued in Zhao (2014), the public pension program can increase the aggregate health spending via two channels. First, the public pension program transfers resources from the young to the elderly, whose marginal propensity to spend on health care is much higher than the young, thus raising aggregate health spending. For example, if the marginal propensities to spend on health care for the young and for the elderly are 0.09 and 0.4 respectively, then transferring one dollar from the young to the elderly would increase aggregate health spending by 31 cents.9 Second, the public pension program raises expected future utility by providing annuities in the later stages of life and insuring for uncertain lifetimes. As a result, it increases the marginal benefit from investing in health to increase longevity, and thus induces people to spend more on health care. It is worth mentioning that this mechanism has also been noted in several earlier studies (Davies and Kuhn (1992), Philipson and Becker (1998)), which argued theoretically that mortality-contingent claims, such as Social Security annuities, may have positive effects on health spending and longevity.

Using numerical simulation techniques, Zhao (2014) shows that the effect of public pension on aggregate health spending is quantitatively important. To the best of our knowledge, however, no previous study has empirically investigated this hypothesis. This paper aims to fill this gap in the literature.

It is also worth mentioning that some people may think that public pension wealth crowds out

\footnotetext{
${ }^{9}$ According to Follette and Sheiner (2005), elderly households spend a much larger share of their income on health care than non-elderly households. For instance, they find that in the US, the elderly in the 3rd income quintile spend $40 \%$ of their income on health care, while health spending is only $9 \%$ of income for the non-elderly in the 3rd income quintile in 1987.
} 
the private savings of agents with rational expectation, which can offset the impact of the abovedescribed mechanisms. This is not exactly true. It has been well argued in the literature that public pension in a model with frictions can transfer resources from the young to the elderly (e.g., Imrohoroglu et al. (1995), and Attanasio and Brugiavini (2003)). For instance, public pension payments are usually larger than the private savings of poor people and people who live longer than expected. Future pension wealth cannot crowd out savings motivated by precautionary reasons because it is not liquid and cannot be borrowed against. Furthermore, a public pension reduces the aggregate capital level and thus increases the interest rate, which also induces people to allocate more resources to the later stage of life. In fact, several empirical studies have suggested that the substitutability between private savings and public pension wealth can be as low as 0.2 , which means one dollar of public pension wealth only crowds out 20 cents of private savings (Diamond and Hausman (1984), Samwick (1997)).

\section{$3 \quad$ Data and Empirical Strategy}

\subsection{Data}

The data used in this paper are compiled from two sources: the OECD 2013 Health Data File and a dataset contains OECD countries' politics-related variables used in Potrafke (2009) and Potrafke (2010). The data from the OECD 2013 Health Data File include 21 countries: ${ }^{10}$ Australia, Austria, Belgium, Canada, Denmark, Finland, France, Germany, Greece, Ireland, Italy, the Netherlands, New Zealand, Norway, Portugal, Spain, Sweden, Switzerland, Turkey, the United Kingdom and the United States. Health expenditure, GDP, public pension, working hours of working age person, the share of public health expenditure, and the share of different groups of elderly population for these countries are observed for the period 1980-2005, and the panel is mostly balanced. Health expenditure, GDP and public pension are all measured in per capita terms and in 2005 US dollars. Politics-related variables including election date, government ideology, parliament information, etc. associated with each of those 21 countries for 1980-2005 were obtained by merging the OECD dataset with the data used in Potrafke (2009) and Potrafke

\footnotetext{
${ }^{10}$ The countries are chosen to maximize the observations.
} 
(2010), as well as some historical records collected online. 11

Table 1 provides simple descriptive statistics of the data (aggregation over countries and years). Figure 1 presents the variation of all the variables excluding the political ones. Panel (a) illustrates the change of the variables in level and in panel (b) we normalize each variable's value in 1980 to be unit. Several observations form from the figure: First, both health expenditure and public pension follow a similar trend: the average health expenditure per capita of 21 countries increases from $\$ 1400$ to $\$ 3100$ (about 2.2 times) from 1980 to 2005 and in the same period the public pension per capital experiences a similar pattern of increasing: it almost doubled from $\$ 1000$ to $\$ 1900$. Second, panel (b) shows that both health expenditure and public pension increase faster than GDP. Especially, from 1980 to 1990 health expenditure and public pension have risen at nearly the same rate, while health expenditure increases faster afterward. In Figure 2. we visualize the relationship between health expenditure and public pension, where panel (a) includes all the observations for 21 countries during the period 1980-2005 and in panel (b) we take average of all the countries in each year. The figure reveals a positive and strong correlation between health expenditure and public pension without taking into account other variables. Notably, the USA spent much more on health care and it represents the "vertical outliers" in panel (a).

\subsection{Empirical Strategy}

\subsubsection{Baseline model}

To investigate the effect of public pension on health expenditure, we propose a static linear panel data model with the following specification:

$$
\begin{aligned}
\log H_{i t} & =\alpha_{i}+\sum_{j=1}^{9} \beta_{j} \log X_{i j t}+\sum_{k=1}^{5} \gamma_{k} Y_{i k t}+\eta_{t}+\varepsilon_{i t} \\
i & =1,2, \cdots, 21 ; \quad t=1,2, \cdots 25
\end{aligned}
$$

\footnotetext{
${ }^{11}$ The politics-related variables are not available for Belgium, Finland, France, Greece, Switzerland, and Turkey in the dataset used by Potrafke (2009) and Potrafke (2010). We collected the missing data from the historical records available online. For instance, the records for Belgium can be found at http://en.wikipedia.org/wiki/Belgian_federal_election,_2014.
} 
where the subscript $i$ indicates country and $t$ indicates year. The dependent variable $H_{i t}$ is health expenditure per capita. $X_{i j t}$ contains the following exogenous variables that may affect health expenditure,

- $G D P_{i t}=$ GDP per capita measured in 2005 U.S. dollars.

- $P P_{i t}=$ the size of Public Pension, which is measured by public pension payments per elderly person (age 65 and above). This variable is simply constructed by dividing the total public spending on old-age and survivors pensions by the number of elderly persons. ${ }^{12}$

- $L_{i t}=$ the average annual hours worked per working-age person, defined as employment rate times average annual hours worked per worker.

- Pop65 - 69, Pop70 - 74, Pop75 - 79, Pop80 - 85, Pop85+ = respectively the population shares of the people between age 65 to 69,70 to 74,75 to 80,81 to 85 and above 85 .

- $P H_{i t}=$ the generosity of the public health insurance, which is measured by public health spending as a share of total health spending.

The parameters $\beta_{j}, j=1,2, \cdots, 9$ are coefficients for $G D P_{i t}, P P_{i t}, \cdots$ and $P H_{i t}$, respectively and $\beta_{2}$ is of special interest in this paper. To better describe the causal relationship between health expenditure and the independent variables $X_{i j t}$, we follow the literature (e.g., Gerdtham et al. (1992a)) and take logarithm for each variable. GDP is a generally accepted explanatory variable in the literature that contributes most to the increase of health expenditure. Public pension in our model is measured by its level per elderly person (age 65 and above) instead of its share of $G D P$ as this leads to a straightforward interpretation of the coefficient of $G D P_{i t}$ : Suppose public pension is measured by its share of $G D P$, then $\log (P P / G D P)=\log P P-$ $\log G D P$ and $G D P$ 's effect on health expenditure would be $\beta_{1}-\beta_{2}$. The variable $L$, "the average annual hours worked per working-age person" is included to test the hypothesis recently proposed in He and Huang (2013): both leisure time and health care are inputs in the production of good health, therefore leisure time is a substitute for spending on health care. Public health insurance policies can also affect health spending because they reduce the effective price of health care for the consumers. Here we use the share of public health spending in total health spending

\footnotetext{
${ }^{12}$ Note that the public spending on old-age and survivors' pensions does not include pension payments through autonomous programmes to former civil servants. Please see Adema et al. (2011) for a detailed description of the measure.
} 
to measure the generosity of the public health insurance policies and thus control for such effects. The population of age 65 or above are eligible to public pension and their spending on health care is arguably high and it is well known that health care spending increases significantly with age. ${ }^{13}$ To account for the impact of population structure and capture the large variation within this age group in per-capita health care spending, we further classify the population of age 65 or above to five groups described above.

With these commonly used explanatory variables included in our static model (1), we may still be at risk of obtaining biased estimates of public pension's effect on health expenditure. Two main channels that could lead to such bias are (1) some omitted variables that cause policymakers to increase the generosity of public pension programs, e.g., election. Such omitted variables may also affect health-related public policies and thus cause biases in our estimates 14 (2) Similarly, policymakers may increase the generosity of public pensions in response to predictable increases in health care costs. Our estimates may suffer from respectively omitted variable and simultaneous equation biases through the two channels. To control for the potential factors above that could bias our estimates, we incorporate some "political variables" $Y_{i k t}$ into model (1).

- Election $_{i t}=\frac{(M-1)+d / D}{12}$ in election year for country $i$, where $M$ is the month of the election, $d$ is the day of the election and $D$ is the number of days in that month. Election El $_{\text {takes }}$ value zero in non-election year.

- Ideology $y_{i t}=$ government ideology, ranging from 1 to 5. Following Potrafke (2009), this variable takes the value 5 if the share of governing left-wing parties in terms of seats in the cabinet and in parliament is larger than $2 / 3$, and 4 if it is between $1 / 3$ and $2 / 3$. The index is 3 if the share of central parties is $50 \%$, or if the left-wing and right-wing parties form a coalition government that is not dominated by one side or the other. The index is symmetric and takes the values 2 and 1 if the right-wing parties dominate.

- $M i n_{i t}=1$ when the government does not have a majority in parliament, and 0 otherwise.

- $C o a l \_2 \_3_{i t}=1$ if a government is a coalition one with two or three parties, and 0 otherwise.

\footnotetext{
${ }^{13}$ For example, Zhao (2014) shows that the spending for age 75 and above is substantially higher than those for age 65 to 74 . The data from Centers for Medicare \& Medicaid Services also reveals that health care spending for those $85+$ is twice as large as for those $65-84$ in US.

${ }^{14}$ Note that this issue is partly controlled by the variable, $P H_{i t}$, public health spending as a share of total health spending. However, as public health policies are usually complicated, this variable may not fully control the generosity of public health policies.
} 
- Coal $_{-} 4_{i t}=1$ if a government is a coalition one with four or more parties, and 0 otherwise.

- $\gamma_{k}, k=1,2, \cdots, 5$ is coefficient for Election Elt $_{\text {Ideology }}, \cdots$ and Col_ $_{i t}$, respectively.

The political variables above respectively control for the effect of election years (Election $i t$ ), the government ideology (Ideology $y_{i t}$ ), whether the government has a majority in parliament $\left(\operatorname{Min}_{i t}\right)$ and the number of partners if a government is a coalition one (Col_2 $\_3_{i t}$ and Col_ $\left.4_{i t}\right)$. Using 18 OECD countries for 1974-2004, Potrafke (2010) show that incumbents increase the growth of public health expenditure for the purpose of election. Since policymakers may also increase the generosity of public pension for the same political concerns, there can be a positive correlation between public pension and aggregate health expenditure that causes an upward bias in our estimates (the first channel we discussed above). By including the political variables, we expect to control for the political factors that may cause bias in our estimates. On the other hand, the rising health care cost can generate political pressure on the government to increase the generosity of public pension (the second channel of bias as we discussed above). If the rising health care cost affects government policies mainly through affecting the political factors captured by our political variables, including these variables can also help us alleviate the reverse causality between public pension and aggregate health expenditure. In other words, the second channel of bias that we discussed above may also be closed by adding the political variables.

In specification (1), we include both time-invariant country effects $\alpha_{i}$ and the time-specific effects $\eta_{t}$ to capture heterogeneity across countries and years. We adopt the usual approach to treat the time-specific effects as fixed and estimate them as the coefficients of time dummies that are included in the regressors, i.e., $\eta_{t} \equiv \sum_{s=2}^{T} \rho_{s} d_{s, i t}$ where $\rho_{s}$ are coefficients and the 21 country dummies $d_{s, i t}$ equal one if $t=s$ and equal zero otherwise 15 The analysis differs according to whether the country-specific effects are treated as fixed or random while in both cases OLS can be employed for estimation (see section 21.8.4 in Cameron and Trivedi (2005)). To test the fixed effects versus random effects, we utilize a robust version of the auxiliary regression for the Hausman test (Wooldridge (2010)). Specifically, we first run an auxiliary regression:

$$
\log H_{i t}=\beta_{0}+\sum_{j=1}^{9} \beta_{j} \log X_{i j t}+\sum_{k=1}^{5} \gamma_{k} Y_{i k t}+\overline{\boldsymbol{Z}}_{i}^{\prime} \boldsymbol{\delta}+\eta_{t}+\xi_{i}+\varepsilon_{i t}
$$

\footnotetext{
${ }^{15}$ There is no intercept in model (1) because if an intercept is included then one of the 21 country dummies must be dropped.
} 
where $\alpha_{i} \equiv \beta_{0}+\overline{\boldsymbol{Z}}_{i}^{\prime} \boldsymbol{\delta}+\xi_{i}$ (Mundlak (1978)), $\beta_{0}$ is a constant, $\xi_{i}$ has mean zero and is uncorrelated with all independent variables $X$ and $Y, \bar{Z}_{i}$ is a vector of time average for all the 14 time-varying independent variables in equation (1) and $\boldsymbol{\delta}$ is the corresponding vector of coefficients ${ }^{16}$ Note that $\boldsymbol{\delta}$ measures the correlation between the heterogeneity $\alpha_{i}$ and the explanatory variables $\left(\log X_{i j t}, Y_{i k t}\right)$. As discussed in Wooldridge $(2010)$, testing $H_{0}: \boldsymbol{\delta}=0$ v.s. $H_{1}: \boldsymbol{\delta} \neq 0$ is the same as basing the test on the random effects and fixed effects estimate. The model above is estimated using pooled OLS and the cluster-robust standard errors are used to allow for heteroscedasticity and serial correlation. A robust Wald statistic is then utilized for testing and the fixed effects model is preferred if the null hypothesis is rejected. This robust version of the auxiliary regression for the Hausman test does not impose the assumption that $\alpha_{i}$ and $\varepsilon_{i}$ are i.i.d. in the hypothesized random effects model, thus it is preferred to the regular Hausman test where such assumption is necessary because the i.i.d. assumption is unlikely given possible heteroskedasticity in the data.

\subsection{Additional specification checks}

Some possible issues, e.g., dynamic effects of health expenditure, unobserved policy changes, etc. may affect our estimation of baseline model (1). For robustness checks, we present in this section several model specifications that extend the baseline model and discuss the corresponding strategies of estimation.

\subsubsection{Dynamic effects}

Dynamic effects, i.e., correlation over time of health expenditure (we specifically consider the correlation between $\log H_{i t}$ and $\log H_{i, t-1}$ ) may present for two possible reasons: (1) Health expenditure in last period determines the expenditure this period. The spending on the treatment of patients with chronic diseases is an example that leads to such correlation. (2) Unobserved heterogeneity leads to a high country-specific effects $\alpha_{i}$ in each year. For example, climate change, which may be serially correlated, will likely lead to hotter days and more frequent and longer heat waves. This could increase the number of heat-related illnesses and deaths, and in turn increase the health expenditure. In order to take into account the possible dynamic effects of health expenditure, we consider the following dynamic model where the health expenditure

\footnotetext{
${ }^{16}$ Note that $\eta_{t}$ cannot be included in $\bar{Z}_{i}$ because the time average of $\eta_{t}$ would be constant across all $i$.
} 
depends on both its lagged value and those explanatory variables in the specification (1).

$$
\log H_{i t}=\rho \log H_{i, t-1}+\alpha_{i}+\sum_{j=1}^{9} \beta_{j} \log X_{i j t}+\sum_{k=1}^{5} \gamma_{k} Y_{i k t}+\eta_{t}+\varepsilon_{i t}
$$

where $|\rho|$ is assumed to be less than one. As is well-known, standard panel estimators such as OLS, within estimator are inconsistent for both fixed effects in the dynamic model above ${ }^{17}$ For example, an OLS estimator is inconsistent because $\log H_{i, t-1}$ is correlate with $\alpha_{i}$ due to the fact that $\log H_{i, t-1}=\rho \log H_{i, t-2}+\alpha_{i}+\sum_{j=1}^{9} \beta_{j} \log X_{i j, t-1}+\sum_{k=1}^{5} \gamma_{k} Y_{i k, t-1}+\eta_{t-1}+\varepsilon_{i, t-1}$. The estimating strategy we adopt is the Arellano-Bond (GMM) estimator proposed in Arellano and Bond (1991), and lagged values of health expenditure are used to be instrumental variables. Specifically, when we estimate the first difference model from (3),

$$
\begin{aligned}
\log H_{i t}-\log H_{i, t-1} & =\rho\left(\log H_{i, t-1}-\log H_{i, t-2}\right)+\sum_{j=1}^{9} \beta_{j}\left(\log X_{i j t}-\log X_{i j, t-1}\right) \\
& +\sum_{k=1}^{5} \gamma_{k}\left(Y_{i k t}-Y_{i k, t-1}\right)+\eta_{t}-\eta_{t-1}+\varepsilon_{i t}-\varepsilon_{i, t-1},
\end{aligned}
$$

both $\left(\log X_{i j t}-\log X_{i j, t-1}\right)$ and $\left(Y_{i k t}-Y_{i k, t-1}\right)$ will be correlated with $\left(\varepsilon_{i t}-\varepsilon_{i, t-1}\right)$ because (3) implies $\log X_{i j t}$ and $Y_{i k t}$ are correlated with $\varepsilon_{i t}$. Under the assumption that $\varepsilon_{i t}$ are serially uncorrelated, it is easy to verify that $\log H_{i, t-2}, \log H_{i, t-3}$, etc. are valid instruments for $\left(\log H_{i, t-1}-\log H_{i, t-2}\right)$. It is always possible to choose more than one instruments while the only parameter of interst is $\rho$, thus the model is overidentified and Arellano and Bond (1991) proposed panel GMM estimators for dynamic panel data models as (3). The validity of the instrumental variables are tested using the Sargan over-identification test with a null hypothesis being "the instruments as a group are exogenous".

\subsubsection{Policy changes}

Public pension systems and their reforms are in a constant state of flux driven by shifting objectives, moving reform needs, and a changing enabling environment. Especially, the early 1990s witnessed reforms of public pension systems for many European countries. For example,

\footnotetext{
${ }^{17}$ Inconsistency also arises for the random effects estimator, please see chapter 22 in Cameron and Trivedi (2005).
} 
Germany introduced a fundamental reform to its public pension system since 1992 to respond to population aging. This reform abolishes the indexation of pensions to gross wages in favor of net wages (Wilke (2009)). The reforms on the public pension systems may change their impact on health expenditure that is not captured by model specification (1). We provide two alternative approaches to control for such effect: first, we consider another model specification by adding a country-specific linear time trend to the specification (1).

$$
\log H_{i t}=\alpha_{i}+\sum_{j=1}^{9} \beta_{j} \log X_{i j t}+\sum_{k=1}^{5} \gamma_{k} Y_{i k t}+\eta_{t}+D_{i} t+\varepsilon_{i t}
$$

where $D_{i}$ is an indicator for country $i$, taking value 1 for country $i$ and 0 for all others. This specification allows some policy changes that occur in a specific country throughout the period of analysis affect health expenditure.

An alternative approach to account for the possible effects of policy changes is to analyze the effects of public pension on health expenditure for different policy periods. A natural dividing point would be 1991, the year "Iron Curtain" fell because some countries in central and eastern Europe have implemented radical pension reforms and economy activities in Europe are changing dramatically since then. Thus, we conduct the previous analysis for the time periods from 1980 to 1991 and from 1992 to 2005 to check the possible effects of (unobserved) policy changes on the causal relation between public pension and aggregate health expenditure 18

\section{Estimation Results}

We present the results of the baseline static model in table 2 for fixed effects. According to the results of auxiliary regression test in this table, the model of fixed effects is more plausible in most of the specifications except model (iv) (at the $5 \%$ significant level) hence we focus on the discussion of results for fixed effects. The estimated effect of public pension on health expenditure is consistently significant and quantitatively stable, ranging from 0.27 to 0.35 , across different specifications. Approximately, the estimate implies that one percent increase in the size of public pension leads to approximately a $1 / 3$ percent increase in health spending per capita,

\footnotetext{
${ }^{18}$ Potrafke (2010) also checks the effects of political determinants on public health expenditure before and after the "iron curtain" fell.
} 
which is consistent with the theoretical and numerical findings in Zhao (2014). Since public pension payments per elderly person on average has increased by $90 \%$ in the set of OECD countries during 1980-2005, our estimate predicts that the expansion of public pension should have generated an increase of $30 \%$ in health expenditure per capita, which is approximately over one fifth of the rise in health expenditure in these OECD countries during the same period. In addition to the estimates of the coefficient, the important role public pension plays in explaining variation of health expenditure is also indicated by the goodness-of-fit $\left(R^{2}\right)$ across the different specifications. Note that the overall $R^{2}$ for those specifications excluding public pension drops dramatically from 0.9 to 0.78 (model (iii)) and 0.61 (model (vii)).

The estimated effect of GDP on health expenditure ranges from 0.66 to 0.80 , which is consistent with the recent results in Acemoglu et al. (2013). By instrumenting for local area income with time series variation in oil prices interacted with local oil reserves, Acemoglu et al. (2013) found that the effect of GDP on health spending is from 0.7-1.1. As a result, our results further reinforce the finding in the literature that health care is not a luxury good, e.g., in Blomqvist and Carter (1997). The results of specifications (ii), (iii), (iv), (v), (vii), and (viii) imply that the impact of labor supply on health expenditure is ambiguous: the variable "the average annual hours worked per working-age person" has a significant effect on health expenditure per capita in our baseline specification (model (i), (v) and (viii)), but the estimated effect is neither consistent nor stable across different model specifications. For instance, the estimates are almost opposite in model (iii) and (iv).

The results from some of our specifications, especially when two time periods are considered (tables 6), show that aggregate health expenditure is higher for a coalition government. Nevertheless, we did not find consistently significant effects of the political variables on aggregate health expenditure, which is somewhat in contrast to some existing studies. As shown in Potrafke (2010) and Herwartz and Theilen (2014), political factors are important for understanding public health expenditure. The reason for the discrepancy between our result and theirs may be that public health expenditure has a crowding out effect on private health expenditure. For instance, according to the analysis in Potrafke (2010), private health expenditure is negatively correlated with public health expenditure after controlling for the political variables and some other covariates. When the substitution between public and private health expenditure is significant, it can offset the effect of the political variables on public health expenditure and thus the 
impact on aggregate health expenditure is ambiguous 19

Lastly, both the share of elderly population and the share of public health expenditure are not the main determinants of the aggregate health expenditure, which confirms the existing results, e.g., see Gerdtham and Jonsson (2000).

Table 3 reports the estimation results of the dynamic model. The $p$-value of Sargan test justifies the validity of the instrumental variables (lagged health expenditure) in all models except (ii) and (vii) at the 5\% significance level. More specifically, except for the first and fifth specifications, the testing results suggest that at the $5 \%$ significance level, we cannot reject the null hypothesis that the instrumental variables we chose are exogenous. The results in table 3 are quantitatively different from the static model. As expected, both GDP and public pension have smaller effects on health expenditure after we take into account the lagged health expenditure. While the size of the effects for both variables is about one half of that in a static model, the results are still consistent and stable across all specifications. It is important to understand the economic meaning of the different results between the static and dynamic models and that the results for the static model and the dynamic one are not inconsistent. In a dynamic panel data model (3), the effects of regressors can be interpreted as short-run effects as opposed to long-run ones. For ease of exposition, suppose public pension is the only explanatory variable in (3) in addition to the lagged health expenditure. Then one percent increase of public pension will cause health expenditure to rise $\beta_{2}$ percent at period $t$, and in period $t+1$ health expenditure will continue to increase, since past expenditure has a positive effect: $\rho \beta_{2}$, another effect $\rho^{2} \beta_{2}$ will be added in period $t+2, \ldots$ It can be easily shown that the sum of all these effects, i.e., the long-run effect of public pension is $\beta_{2} /(1-\rho)$, which is much larger than $\beta_{2}$ for not very small $\rho$.

The results with country-specific time trend included into the baseline model are presented in tables 4.5. Again, the fixed effects model is preferred according to the results of auxiliary regression tests in table 4. Comparisons between the results of tables 4 and 5 respectively with tables 2 and 3 show that the effect of public pension is robust to country-specific unobserved factors. Notably, the effects of GDP reported in table 4 are consistently smaller than that in table 2. This may be due to the possibility that those unobserved policy changes are strongly correlated with GDP but not public pension, for example, the development of internet. Consequently, the

\footnotetext{
${ }^{19}$ Another possible reason for the discrepancy between our results and theirs is the choice of sample. Potrafke (2010) and Herwartz and Theilen (2014) use 17 OECD countries for 1971-2004, and 21 OECD countries for 1971-2008, respectively.
} 
effect of GDP would be smaller after we control for the unobserved policy changes while the effect of public pension is intact.

Tables 6 6 7 report the estimates for two policy periods: 1980-1991 and 1992-2005. In general, the results are very similar to the previous estimates. Nevertheless, the estimates do reveal discrepancy between two periods and the results for the period 1980-1990 are relatively noisy. For example, the estimated impact of GDP is insignificant in the fixed effects model (table 6) and consistently exceeds 1 in the dynamic model (table 7) for the period 1980-1990. Astonishingly, public pension still has a consistently significant effect on health expenditure for both periods and across all the specifications. Notably, the effect of public pension is quantitatively larger for the period 1992-2005, which implies that the impact of public pension on health expenditure is not only significant but also increasing.

\subsection{Further discussions on the rise in health spending}

It is well known that aggregate health spending in developed countries has increased dramatically over the last decades. As shown in table 8, health spending per capita in developed OECD countries was on average only $\$ 1378$ in 1980 and it increased to $\$ 3152$ in 2005 (by a factor of 2.3). Why has health spending risen so much over the last several decades? This question has attracted growing attention in the literature. Our empirical estimation of the determinants of aggregate health expenditure can also shed some lights on this question. In particular, we identified a new determinant, the size of public pension, and thus have provided a new potential explanation for the dramatic rise in health spending. As also shown in table 8, public pension payments per elderly person has on average increased by a factor of 1.9 in these OECD countries during 1980-2005. Therefore, a simple back of the envelope calculation based on our baseline estimate suggests that the expansion of public pension can generate a $30 \%$ increase in health spending per capita, which is approximately over one fifth of the average rise in health spending in these OECD countries during $1980-2005$.

Among the other explanatory variables, GDP per capita is the main existing explanatory variable for aggregate health spending. There has been a long debate on whether the growth of GDP per capita is the main driver of the health spending growth. Note that since health spending grows faster than GDP per capita in developed countries over the last several decades, 
the debate is sometimes also phrased as whether health care is a luxury good. As shown in table 8, the average GDP per capita in these OECD countries increased by a factor of 1.7 from 1980 to 2005. As a result, aggregate health spending as a share of GDP increased from $6.7 \%$ to $9.6 \%$ over the same period. Based on our estimated effect of GDP per capita on health spending, the increase in GDP per capita accounts for approximately two fifths of the rise in health spending in absolute value terms. However, the estimated effect of GDP per capita is significantly less than one among most model specifications, suggesting that health care is not a luxury good. In other words, the increase in GDP per capita cannot be the reason why health spending as a share of GDP has risen so much.

Our estimation results also provide evidence for several other hypotheses. For instance, the estimated coefficients for the elderly population shares are all insignificant in specification (viii) (the baseline specification), which suggests that population aging may not be an important cause of the rise in health spending. The public health share (measured as public health spending as a share of total health spending) has a significant impact on health spending. In specification (viii), a one percentage increase in the public health share leads to a 0.36 percentage increase in health spending. However, since the public health share has not increased much from 1980 to 2005, it cannot be an important cause of the rapid rise in health spending. It is worth noting that if the public pension variable is not included into the regression model, the public health share has a significantly larger effect on health spending. This suggests that in existing regression models without the public pension variable, the public health share variable may have simply picked up the effect of public pension as the two variables are highly correlated with each other.

Our analysis also includes the aggregate labor supply variable (measured by average hours worked per working-age person), which is another new variable motivated by recent theoretical studies. As mentioned previously, He and Huang (2013) have recently argued that both leisure time and health care are inputs in the production of good health, therefore leisure time is a substitute for spending on health care. According to this theory, aggregate labor supply should have a positive effect on aggregate health spending. In a quantitative dynamic macro model with health capital, they show that an important reason why Americans spend much more on health care than Europeans is that Americans also work much more. In our main specification (specification (vi)), the estimated effect of aggregate labor supply on health spending is significant at the $1 \%$ level. A one percent increase in average hours worked leads to a $0.31 \%$ increase in health spending. However, this result needs to be treated with caution as the effect of aggregate 
labor supply is not stable across different model specifications ${ }^{20}$ In addition, as can be seen in table 8, the aggregate hours worked per working-age person has not significantly increased from 1980 to 2005, therefore it cannot be an important driver for the rapid rise in health spending over the same period 21

\section{Conclusion}

We empirically investigated the determinants of aggregate health spending with special attention to several new determinants that are motivated by recent theoretical advances in the literature. We have identified an important new determinant of aggregate health spending, that is, the size of the public pension program. We found that a one percentage increase in public pension payments per elderly person would lead to approximately a $1 / 3$ percentage increase in health spending per capita. A back of the envelope calculation based on our estimation suggests that the expansion of public pension can account for one fifth of the rise in health spending as a share of GDP in the set of OECD countries over 1980-2005. Our empirical results confirm the theoretical and numerical findings in Zhao (2014). We also included a variable for aggregate labor supply variable (i.e., average hours worked per working-age person) in our model, another possible new determinant of health spending as suggested by some recent studies in the literature. However, our results showed that the effect of aggregate labor supply on health spending is ambiguous. Finally, we found that the estimated effect of GDP per capita (i.e., the main existing explanatory variable) ranges from 0.66 to 0.80 in our model, which is consistent with the results in previous studies, and thus further reinforces the finding in the literature that health care is not a luxury good, and income growth may not be an important reason why health spending as a share of GDP has risen so much.

\footnotetext{
${ }^{20}$ As can be seen in table 2 the effect of aggregate labor supply becomes insignificant in all other specifications, and in some specifications even the sign differs.

${ }^{21}$ Note that our results are not necessarily in contrast to the findings in He and Huang $(2013)$. As Americans work approximately $30 \%$ more hours than Europeans, different aggregate labor supply may explain a significant portion of the difference in aggregate health spending between the US and Europe if the estimated effect of labor supply on health spending is positive and significant.
} 


\section{References}

Acemoglu, Daron, Amy Finkelstein, and Matthew J Notowidigdo, "Income and health spending: evidence from oil price shocks," Review of Economics and Statistics, 2013, 95 (4), 1079-1095.

Adema, W., P. Fron, and M. Ladaique, "Is the European Welfare State Really More Expensive?: Indicators on Social Spending, 1980-2012; and a Manual to the OECD Social Expenditure Database (SOCX)," OECD Social, Employment and Migration Working Papers, No.124, OECD Publishing, 2011.

Arellano, Manuel and Stephen Bond, "Some tests of specification for panel data: Monte Carlo evidence and an application to employment equations," The review of economic studies, $1991,58(2), 277-297$.

Attanasio, Orazio and Agar Brugiavini, "Social Security and Households' Saving," Quarterly Journal of Economics, August 2003, pp. 1075-1119.

Blomqvist, A. G. and R. A. L. Carter, "Is health care really a luxury?," Journal of Health Economics, April 1997.

Cameron, A Colin and Pravin K Trivedi, Microeconometrics: methods and applications, Cambridge university press, 2005.

CBO, "Technological Change and the Growth of Health Spending," 2008, Congressional Budget Office paper.

Davies, James and Peter Kuhn, "Social Security, Longevity, and Moral Hazard," Journal of Public Economics, 1992, 49.

Diamond, Peter and Jerry Hausman, "Individual Retirement and Savings Decisions," Journal of Public Economics, 1984, pp. 81-114.

Finkelstein, Amy, "The Aggregate Effects of Health Insurance: Evidence from the Introduction of Medicare," Quarterly Journal of Economics, 2007, 122(1).

Follette, G. and L. Sheiner, "The Sustainability of Health Spending Growth," Federal Reserve Board Staff Working Paper, 2005, 2005-60. 
Gerdtham, Ulf and Bengt Jonsson, "International Comparisons of Health Expenditure: theory, data and econometric analysis," 2000, in A.L. Culyer and J. Newhouse (eds). Handbook of Health Economics. Amsterdam: Elsevier.

Gerdtham, Ulf-G, Jes Søgaard, Fredrik Andersson, and Bengt Jönsson, "An econometric analysis of health care expenditure: a cross-section study of the OECD countries," Journal of health economics, 1992, 11 (1), 63-84.

Gerdtham, Ulf, J. Sogaard, F. Andersson, and Bengt Jonsson, "Econometric analysis of health expenditure: a cross-sectional study of the OECD countries," Journal of Health Economics, 1992, 11, 63-84.

Hall, Robert and Charles Jones, "The Value of Life and the Rise in Health Spending," Quarterly Journal of Economics, 2007, 122(1).

He, Hui and Kevin X. D. Huang, "Why Do Americans Spend So Much More on Health Care than Europeans? A General Equilibrium Macroeconomic Analysis," 2013, working manuscript.

Herwartz, Helmut and Bernd Theilen, "Health care and ideology: a reconsideration of political determinants of public healthcare funding in the OECD," Health economics, 2014, 23 (2), 225-240.

Imrohoroglu, Ayse, Selahattin Imrohoroglu, and Douglas H. Joines, "A Life Cycle Analysis of Social Security," Economic Theory, 1995, 6, 83-114.

Mundlak, Yair, "On the pooling of time series and cross section data," Econometrica: journal of the Econometric Society, 1978, pp. 69-85.

Newhouse, Joseph P., "Medical Care Costs: How Much Welfare Loss?," Journal of Economic Perspectives, 1992, 6(3), 3-21.

Philipson, Tomas and Gary Becker, "Old-Age Longevity and Mortality-Contingent Claims," Journal of Political Economy, 1998, 106(3).

Potrafke, Niklas, "Did globalization restrict partisan politics? An empirical evaluation of social expenditures in a panel of OECD countries," Public Choice, 2009, 140 (1-2), 105-124. 
_ , "The growth of public health expenditures in OECD countries: do government ideology and electoral motives matter?," Journal of health economics, 2010, 29 (6), 797-810.

Samwick, Andrew, "The Impact of Social Security Reform on Saving," National Tax Association Proceedings, 1997, pp. 178-186.

Suen, Richard M. H., "Technological Advance and the Growth in Health Care Spending," 2006, unpublished manuscript, UC Riverside.

Wilke, Christina Benita, German pension Reform: On Road towards a Sustainable MultiPillar System, Vol. 34, Peter Lang, 2009.

Wooldridge, Jeffrey M, Econometric analysis of cross section and panel data, MIT press, 2010.

Zhao, Kai, "Social Security and the Rise in Health Spending," Journal of Monetary Economics, May 2014, 64, 21-37. 


\section{Appendix}

Table 1: Descriptive statistics ${ }^{a}$

\begin{tabular}{|c|c|c|c|c|}
\hline Variable & Mean & Ptd. Dev. & Min & $\overline{\mathrm{Max}}$ \\
\hline Number of countries & 21 & & & \\
\hline Number of years & 25 & & & \\
\hline Health expenditure per capita & 2078.82 & 985.60 & 108.27 & 6734.56 \\
\hline Public pension per elderly person & 1437.83 & 635.52 & 59.07 & 3139.07 \\
\hline Avg. hour worked/working-age person & 1116.45 & 143.18 & 759.06 & 1365.82 \\
\hline GDP per capita & 24786.42 & 7392.27 & 5907.45 & 47639.58 \\
\hline Pub. health expend. share (\%) & 68.31 & 12.28 & 10.71 & 85.82 \\
\hline Pop 65-69 share (\%) & 4.20 & 0.79 & 1.38 & 6.41 \\
\hline Pop 70-74 share (\%) & 3.61 & 0.75 & 1.00 & 5.08 \\
\hline Pop 75-79 share (\%) & 2.76 & 0.73 & 0.14 & 4.09 \\
\hline Pop $80-84$ share $(\%)$ & 1.80 & 0.52 & 0.14 & 2.99 \\
\hline Pop $85+$ share $(\%)$ & 1.28 & 0.46 & 0.14 & 2.46 \\
\hline Election & 0.16 & 0.30 & 0 & 0.98 \\
\hline Ideology & 2.91 & 0.91 & 1 & 5 \\
\hline Coalition (2 or 3 parties) & 0.48 & 0.50 & 0 & 1 \\
\hline Coalition ( 4 or more parties) & 0.13 & 0.33 & 0 & 1 \\
\hline Minority government & 0.42 & 0.49 & 0 & 1 \\
\hline
\end{tabular}


Figure 1: Time trend of averaged variables, 1980-2005 (average of 21 countries)

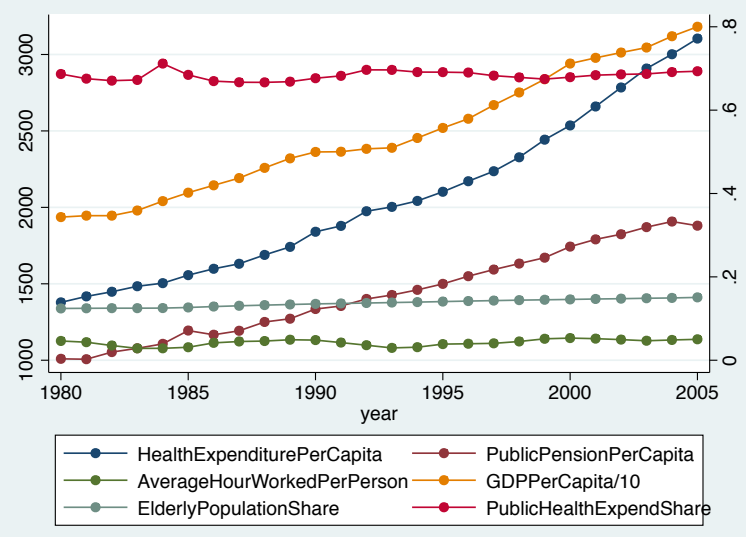

(a) Variables in level, source: OECD (2013). ElderlyPopulationShare is the share of population at age 65 and above.

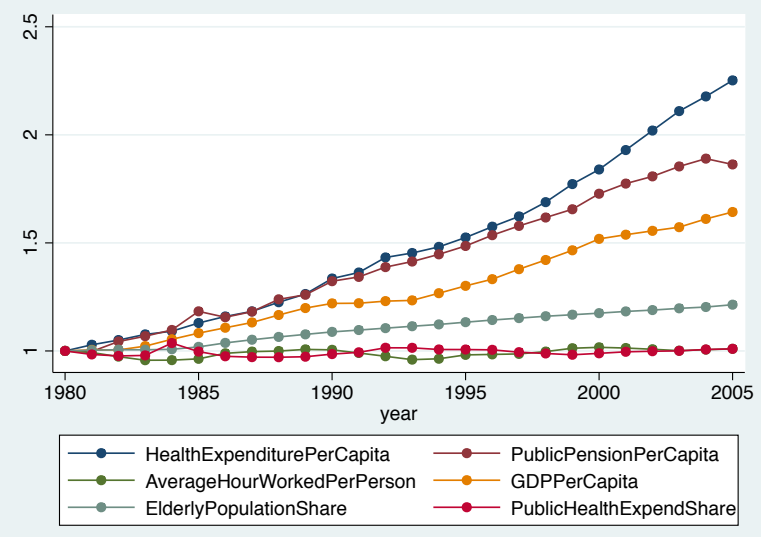

(b) Normalized variables, source: OECD (2013). ElderlyPopulationShare is the share of population at age 65 and above.

Figure 2: Public pension in relation to health expenditure, 1980-2005

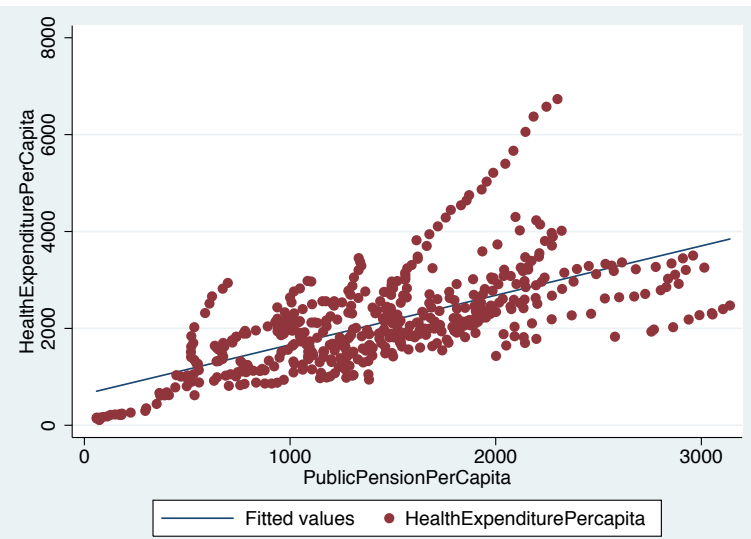

(a) Pooled of 21 countries, source: OECD (2013).

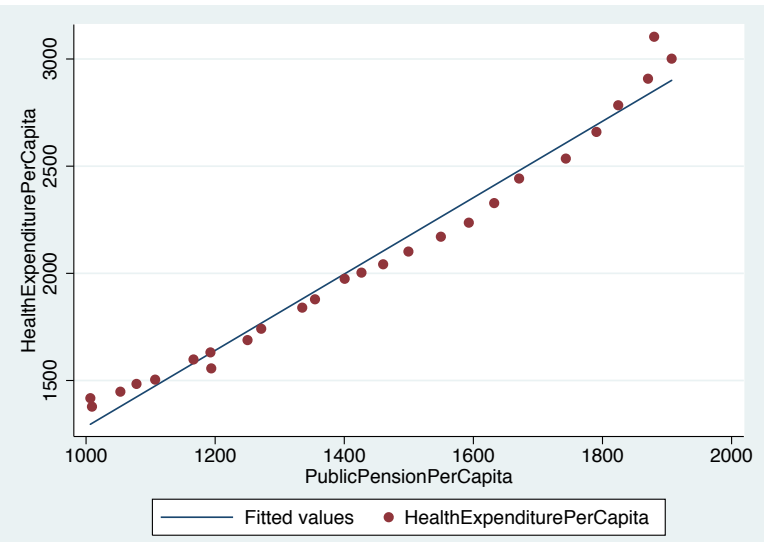

(b) Average of 21 countries, source: OECD (2013). 
Table 2: Regression results of the static model (fixed effects) $)^{a}$

\begin{tabular}{|c|c|c|c|c|c|c|c|c|}
\hline & (i) & (ii) & (iii) & (iv) & 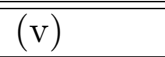 & (vi) & (vii) & (viii) \\
\hline GDP & $\begin{array}{l}0.77^{* * *} \\
(0.11)\end{array}$ & $\begin{array}{l}0.66^{* * *} \\
(0.10)\end{array}$ & $\begin{array}{l}0.80^{* * *} \\
(0.17)\end{array}$ & $\begin{array}{l}0.74^{* * *} \\
(0.09)\end{array}$ & $\begin{array}{l}0.76^{* * *} \\
(0.10)\end{array}$ & $\begin{array}{l}0.80^{* * *} \\
(0.10)\end{array}$ & $\begin{array}{l}0.80^{* * *} \\
(0.18)\end{array}$ & $\begin{array}{l}0.76^{* * *} \\
(0.12)\end{array}$ \\
\hline Public pension & $\begin{array}{l}0.29^{* * *} \\
(0.07)\end{array}$ & $\begin{array}{l}0.28^{* * *} \\
(0.07)\end{array}$ & & $\begin{array}{l}0.30^{* * *} \\
(0.09)\end{array}$ & $\begin{array}{l}0.30^{* * *} \\
(0.08)\end{array}$ & $\begin{array}{l}0.35^{* * *} \\
(0.07)\end{array}$ & & $\begin{array}{l}0.27^{* * *} \\
(0.07)\end{array}$ \\
\hline Avg. hours worked & $\begin{array}{l}0.33^{* *} \\
(0.13)\end{array}$ & & $\begin{array}{l}-0.27 \\
(0.32)\end{array}$ & $\begin{array}{l}0.21 \\
(0.14)\end{array}$ & $\begin{array}{l}0.33^{* * *} \\
(0.11)\end{array}$ & & $\begin{array}{l}0.06 \\
(0.15)\end{array}$ & $\begin{array}{l}0.31^{* *} \\
(0.13)\end{array}$ \\
\hline Pop 65-69 & $\begin{array}{l}0.17 \\
(0.15)\end{array}$ & & & & & $\begin{array}{l}0.15 \\
(0.18)\end{array}$ & $\begin{array}{l}0.24 \\
(0.15)\end{array}$ & $\begin{array}{l}0.19 \\
(0.16)\end{array}$ \\
\hline Pop 70-74 & $\begin{array}{l}-0.03 \\
(0.16)\end{array}$ & & & & & $\begin{array}{l}0.006 \\
(0.14)\end{array}$ & $\begin{array}{l}0.14 \\
(0.14)\end{array}$ & $\begin{array}{l}-0.02 \\
(0.15)\end{array}$ \\
\hline Pop 75-79 & $\begin{array}{l}-0.03 \\
(0.06)\end{array}$ & & & & & $\begin{array}{l}-0.003 \\
(0.07)\end{array}$ & $\begin{array}{l}-0.06 \\
(0.07)\end{array}$ & $\begin{array}{l}-0.01 \\
(0.05)\end{array}$ \\
\hline Pop 80-84 & $\begin{array}{l}0.003 \\
(0.08)\end{array}$ & & & & & $\begin{array}{l}0.03 \\
(0.08)\end{array}$ & $\begin{array}{l}-0.04 \\
(0.07)\end{array}$ & $\begin{array}{l}-0.02 \\
(0.07)\end{array}$ \\
\hline Pop $85+$ & $\begin{array}{l}-0.08 \\
(0.11)\end{array}$ & & & & & $\begin{array}{l}-0.13 \\
(0.13)\end{array}$ & $\begin{array}{l}-0.09 \\
(0.13)\end{array}$ & $\begin{array}{l}-0.10 \\
(0.11)\end{array}$ \\
\hline Pop $65+$ & & & & & $\begin{array}{l}0.10 \\
(0.24)\end{array}$ & & & \\
\hline Pub. health share & $\begin{array}{l}0.37^{*} \\
(0.19)\end{array}$ & & & & $\begin{array}{l}0.38^{*} \\
(0.21)\end{array}$ & $\begin{array}{l}-0.01 \\
(0.10)\end{array}$ & $\begin{array}{l}0.53^{* * *} \\
(0.19)\end{array}$ & $\begin{array}{l}0.36^{*} \\
(0.19)\end{array}$ \\
\hline Election & & $\begin{array}{l}0.002 \\
(0.007)\end{array}$ & $\begin{array}{l}-0.006 \\
(0.005)\end{array}$ & $\begin{array}{l}-0.004 \\
(0.005)\end{array}$ & $\begin{array}{l}-0.00009 \\
(0.005)\end{array}$ & $\begin{array}{l}0.002 \\
(0.008)\end{array}$ & $\begin{array}{l}0.0007 \\
(0.006)\end{array}$ & $\begin{array}{c}-0.0005 \\
(0.005)\end{array}$ \\
\hline Ideology & & $\begin{array}{l}-0.001 \\
(0.005)\end{array}$ & $\begin{array}{l}-0.008 \\
(0.009)\end{array}$ & $\begin{array}{l}-0.005 \\
(0.006)\end{array}$ & $\begin{array}{l}-0.01 \\
(0.01)\end{array}$ & $\begin{array}{l}-0.004 \\
(0.006)\end{array}$ & $\begin{array}{l}-0.004 \\
(0.007)\end{array}$ & $\begin{array}{l}-0.006 \\
(0.005)\end{array}$ \\
\hline Coalition_2_3 & & $\begin{array}{l}0.03 \\
(0.03)\end{array}$ & $\begin{array}{l}0.03 \\
(0.02)\end{array}$ & $\begin{array}{l}0.04 \\
(0.03)\end{array}$ & $\begin{array}{l}0.03^{*} \\
(0.02)\end{array}$ & $\begin{array}{l}0.009 \\
(0.02)\end{array}$ & $\begin{array}{l}0.07 * * * \\
(0.02)\end{array}$ & $\begin{array}{l}0.04^{* *} \\
(0.02)\end{array}$ \\
\hline Coalition_4 & & $\begin{array}{l}0.07 \\
(0.04)\end{array}$ & $\begin{array}{l}0.08 \\
(0.04)\end{array}$ & $\begin{array}{l}0.08 \\
(0.05)\end{array}$ & $\begin{array}{l}0.05 \\
(0.05)\end{array}$ & $\begin{array}{l}0.03 \\
(0.04)\end{array}$ & $\begin{array}{l}0.06 \\
(0.05)\end{array}$ & $\begin{array}{l}0.05 \\
(0.05)\end{array}$ \\
\hline Minority gov. & & $\begin{array}{l}-0.0005 \\
(0.03)\end{array}$ & $\begin{array}{l}-0.01 \\
(0.04)\end{array}$ & $\begin{array}{l}0.004 \\
(0.03)\end{array}$ & $\begin{array}{l}0.01 \\
(0.03)\end{array}$ & $\begin{array}{l}0.007 \\
(0.03)\end{array}$ & $\begin{array}{l}0.03 \\
(0.03)\end{array}$ & $\begin{array}{l}0.02 \\
(0.03)\end{array}$ \\
\hline Year fixed effects & Yes & Yes & Yes & Yes & Yes & Yes & Yes & Yes \\
\hline Auxiliary reg. test ${ }^{b}$ & 0.00 & 0.04 & 0.00 & 0.30 & 0.00 & 0.00 & 0.00 & 0.00 \\
\hline Observations & 395 & 504 & 451 & 440 & 395 & 443 & 406 & 395 \\
\hline R-squared (overall) & 0.82 & 0.90 & 0.78 & 0.89 & 0.80 & 0.91 & 0.61 & 0.80 \\
\hline Number of countries & 21 & 21 & 21 & 21 & 21 & 21 & 21 & 21 \\
\hline
\end{tabular}

${ }^{a}$ Standard errors in parentheses, ${ }^{* * *}$ significant at $1 \%,{ }^{* *}$ at $5 \%$ and ${ }^{*}$ at $10 \%$ level.

${ }^{b}$ This row presents the $p$-value of the auxiliary regression test. 
Table 3: Regression results (dynamic model) ${ }^{a}$

\begin{tabular}{|c|c|c|c|c|c|c|c|c|}
\hline & (i) & (ii) & (iii) & 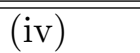 & (v) & (vi) & (vii) & (viii) \\
\hline Lag. health expend. & $\begin{array}{l}0.72^{* * *} \\
(0.09)\end{array}$ & $\begin{array}{l}0.65^{* * *} \\
(0.07)\end{array}$ & $\begin{array}{l}0.47^{* * *} \\
(0.09)\end{array}$ & $\begin{array}{l}0.87^{* * *} \\
(0.14)\end{array}$ & $\begin{array}{l}0.61^{* * *} \\
(0.09)\end{array}$ & $\begin{array}{l}0.37^{* * *} \\
(0.08)\end{array}$ & $\begin{array}{l}0.65^{* * *} \\
(0.10)\end{array}$ & $\begin{array}{l}0.72^{* * *} \\
(0.10)\end{array}$ \\
\hline GDP & $\begin{array}{l}0.23^{* *} \\
(0.09)\end{array}$ & $\begin{array}{l}0.43^{* * *} \\
(0.08)\end{array}$ & $\begin{array}{l}0.48^{* * *} \\
(0.07)\end{array}$ & $\begin{array}{l}0.32^{* * *} \\
(0.10)\end{array}$ & $\begin{array}{l}0.32^{* * *} \\
(0.09)\end{array}$ & $\begin{array}{l}0.34^{* * *} \\
(0.07)\end{array}$ & $\begin{array}{l}0.40^{* * *} \\
(0.08)\end{array}$ & $\begin{array}{l}0.22^{* *} \\
(0.09)\end{array}$ \\
\hline Public pension & $\begin{array}{l}0.12^{* * *} \\
(0.04)\end{array}$ & $\begin{array}{l}0.20^{* * *} \\
(0.03)\end{array}$ & & $\begin{array}{l}0.17^{* * *} \\
(0.04)\end{array}$ & $\begin{array}{l}0.13^{* * *} \\
(0.04)\end{array}$ & $\begin{array}{l}0.15^{* * *} \\
(0.04)\end{array}$ & & $\begin{array}{l}0.13^{* * *} \\
(0.04)\end{array}$ \\
\hline Avg. hours worked & $\begin{array}{l}0.06 \\
(0.09)\end{array}$ & & $\begin{array}{l}-0.09 \\
(0.09)\end{array}$ & $\begin{array}{l}0.03 \\
(0.10)\end{array}$ & $\begin{array}{l}0.01 \\
(0.08)\end{array}$ & & $\begin{array}{l}-0.04 \\
(0.08)\end{array}$ & $\begin{array}{l}0.08 \\
(0.09)\end{array}$ \\
\hline Pop 65-69 & $\begin{array}{l}-0.01 \\
(0.05)\end{array}$ & & & & & $\begin{array}{l}0.03 \\
(0.04)\end{array}$ & $\begin{array}{l}-0.02 \\
(0.05)\end{array}$ & $\begin{array}{l}-0.02 \\
(0.05)\end{array}$ \\
\hline Pop 70-74 & $\begin{array}{l}-0.01 \\
(0.05)\end{array}$ & & & & & $\begin{array}{l}0.05 \\
(0.03)\end{array}$ & $\begin{array}{l}0.05 \\
(0.05)\end{array}$ & $\begin{array}{l}-0.03 \\
(0.06)\end{array}$ \\
\hline Pop 75-79 & $\begin{array}{l}-0.07^{* *} \\
(0.03)\end{array}$ & & & & & $\begin{array}{l}-0.05^{*} \\
(0.03)\end{array}$ & $\begin{array}{l}-0.06^{* *} \\
(0.03)\end{array}$ & $\begin{array}{l}-0.07^{* *} \\
(0.03)\end{array}$ \\
\hline Pop 80-84 & $\begin{array}{l}-0.01 \\
(0.03)\end{array}$ & & & & & $\begin{array}{l}-0.04 \\
(0.03)\end{array}$ & $\begin{array}{l}-0.03 \\
(0.03)\end{array}$ & $\begin{array}{l}-0.02 \\
(0.03)\end{array}$ \\
\hline Pop $85+$ & $\begin{array}{l}0.11^{* *} \\
(0.05)\end{array}$ & & & & & $\begin{array}{l}0.12^{* *} \\
(0.05)\end{array}$ & $\begin{array}{l}0.14^{* * *} \\
(0.05)\end{array}$ & $\begin{array}{l}0.12^{* *} \\
(0.05)\end{array}$ \\
\hline Pop $65+$ & & & & & $\begin{array}{l}0.21^{* *} \\
(0.10)\end{array}$ & & & \\
\hline Pub. health share & $\begin{array}{l}0.006 \\
(0.07)\end{array}$ & & & & $\begin{array}{l}-0.01 \\
(0.07)\end{array}$ & $\begin{array}{l}-0.01 \\
(0.05)\end{array}$ & $\begin{array}{l}-0.03 \\
(0.07)\end{array}$ & $\begin{array}{l}-0.003 \\
(0.07)\end{array}$ \\
\hline Election & & $\begin{array}{l}0.007 \\
(0.006)\end{array}$ & $\begin{array}{l}0.003 \\
(0.005)\end{array}$ & $\begin{array}{l}0.005 \\
(0.005)\end{array}$ & $\begin{array}{l}0.006 \\
(0.005)\end{array}$ & $\begin{array}{l}0.004 \\
(0.005)\end{array}$ & $\begin{array}{l}0.007 \\
(0.005)\end{array}$ & $\begin{array}{l}0.006 \\
(0.005)\end{array}$ \\
\hline Ideology & & $\begin{array}{c}-0.003 \\
(0.004)\end{array}$ & $\begin{array}{c}-0.001 \\
(0.003)\end{array}$ & $\begin{array}{c}-0.002 \\
(0.003)\end{array}$ & $\begin{array}{c}-0.0002 \\
(0.003)\end{array}$ & $\begin{array}{l}-0.001 \\
(0.003)\end{array}$ & $\begin{array}{l}0.0002 \\
(0.003)\end{array}$ & $\begin{array}{c}-0.0002 \\
(0.003)\end{array}$ \\
\hline Coalition_2_3 & & $\begin{array}{l}-0.01 \\
(0.01)\end{array}$ & $\begin{array}{l}0.004 \\
(0.009)\end{array}$ & $\begin{array}{l}-0.003 \\
(0.01)\end{array}$ & $\begin{array}{l}-0.001 \\
(0.01)\end{array}$ & $\begin{array}{l}-0.01 \\
(0.009)\end{array}$ & $\begin{array}{l}0.009 \\
(0.01)\end{array}$ & $\begin{array}{l}-0.002 \\
(0.01)\end{array}$ \\
\hline Coalition_4 & & $\begin{array}{l}0.01 \\
(0.02)\end{array}$ & $\begin{array}{l}0.02 \\
(0.01)\end{array}$ & $\begin{array}{l}0.02 \\
(0.02)\end{array}$ & $\begin{array}{l}0.009 \\
(0.02)\end{array}$ & $\begin{array}{l}-0.008 \\
(0.01)\end{array}$ & $\begin{array}{l}0.01 \\
(0.01)\end{array}$ & $\begin{array}{l}0.01 \\
(0.02)\end{array}$ \\
\hline Minority government & & $\begin{array}{l}0.0003 \\
(0.01)\end{array}$ & $\begin{array}{r}-0.0001 \\
(0.008)\end{array}$ & $\begin{array}{l}0.002 \\
(0.01)\end{array}$ & $\begin{array}{l}-0.008 \\
(0.01)\end{array}$ & $\begin{array}{l}-0.009 \\
(0.008)\end{array}$ & $\begin{array}{l}-0.001 \\
(0.007)\end{array}$ & $\begin{array}{l}-0.008 \\
(0.008)\end{array}$ \\
\hline Instruments (lagged $H)^{b}$ & 2 & 2 & 5 & 4 & 2 & 3 & 2 & 2 \\
\hline Sargan test ( $p$-value) & 0.12 & 0.00 & 0.19 & 0.12 & 0.07 & 0.15 & 0.04 & 0.06 \\
\hline Observations & 393 & 504 & 451 & 440 & 393 & 441 & 404 & 393 \\
\hline Number of countries ${ }^{c}$ & 20 & 21 & 21 & 21 & 20 & 20 & 20 & 20 \\
\hline
\end{tabular}

a Standard errors in parentheses, ${ }^{* * *}$ significant at $1 \%,{ }^{* *}$ at $5 \%$ and ${ }^{*}$ at $10 \%$ level.

${ }^{b}$ The number of lagged dependent variable chosen for insturments. For example, specification (viii) uses two periods' lagged $H$, i.e., $\log H_{i, t-2}$ and $\log H_{i, t-3}$ as instruments for $\left(\log H_{i, t-1}-\log H_{i, t-2}\right)$.

${ }^{c}$ New Zealand has two years' data of population (Year 2004 and 2005), which cannot be used for estimations in (i), (v), (vi), (vii) and (viii). 
Table 4: Regression results with country-specific time trend: fixed effects ${ }^{a}$

\begin{tabular}{|c|c|c|c|c|c|c|c|c|}
\hline & (i) & (ii) & (iii) & (iv) & 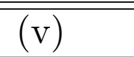 & (vi) & (vii) & (viii) \\
\hline GDP & $\begin{array}{l}0.27 \\
(0.21)\end{array}$ & $\begin{array}{l}0.61^{* *} \\
(0.23)\end{array}$ & $\begin{array}{l}0.40 \\
(0.27)\end{array}$ & $\begin{array}{l}0.29 \\
(0.23)\end{array}$ & $\begin{array}{l}0.39^{*} \\
(0.23)\end{array}$ & $\begin{array}{l}0.68^{* * *} \\
(0.23)\end{array}$ & $\begin{array}{l}0.46^{* *} \\
(0.21)\end{array}$ & $\begin{array}{l}0.26 \\
(0.20)\end{array}$ \\
\hline Public pension & $\begin{array}{l}0.24^{* *} \\
(0.09)\end{array}$ & $\begin{array}{l}0.26^{* *} \\
(0.12)\end{array}$ & & $\begin{array}{l}0.27^{* *} \\
(0.10)\end{array}$ & $\begin{array}{l}0.26^{* *} \\
(0.11)\end{array}$ & $\begin{array}{l}0.23^{* *} \\
(0.09)\end{array}$ & & $\begin{array}{l}0.23^{* *} \\
(0.09)\end{array}$ \\
\hline Avg. hours worked & $\begin{array}{l}0.35^{*} \\
(0.18)\end{array}$ & & $\begin{array}{l}-0.06 \\
(0.20)\end{array}$ & $\begin{array}{l}0.11 \\
(0.16)\end{array}$ & $\begin{array}{l}0.22 \\
(0.18)\end{array}$ & & $\begin{array}{l}0.17 \\
(0.20)\end{array}$ & $\begin{array}{l}0.34^{*} \\
(0.18)\end{array}$ \\
\hline Pop 65-69 & $\begin{array}{l}0.14 \\
(0.13)\end{array}$ & & & & & $\begin{array}{l}0.17 \\
(0.15)\end{array}$ & $\begin{array}{l}0.14 \\
(0.18)\end{array}$ & $\begin{array}{l}0.13 \\
(0.14)\end{array}$ \\
\hline Pop 70-74 & $\begin{array}{l}-0.36 \\
(0.25)\end{array}$ & & & & & $\begin{array}{l}-0.21^{*} \\
(0.12)\end{array}$ & $\begin{array}{l}-0.35 \\
(0.23)\end{array}$ & $\begin{array}{l}-0.37 \\
(0.24)\end{array}$ \\
\hline Pop 75-79 & $\begin{array}{l}-0.10 \\
(0.07)\end{array}$ & & & & & $\begin{array}{l}-0.11 \\
(0.07)\end{array}$ & $\begin{array}{l}-0.10 \\
(0.09)\end{array}$ & $\begin{array}{l}-0.10 \\
(0.08)\end{array}$ \\
\hline Pop 80-84 & $\begin{array}{l}-0.11 \\
(0.07)\end{array}$ & & & & & $\begin{array}{l}-0.16^{* *} \\
(0.08)\end{array}$ & $\begin{array}{l}-0.13^{*} \\
(0.07)\end{array}$ & $\begin{array}{l}-0.12 \\
(0.07)\end{array}$ \\
\hline Pop $85+$ & $\begin{array}{l}0.06 \\
(0.10)\end{array}$ & & & & & $\begin{array}{l}-0.001 \\
(0.12)\end{array}$ & $\begin{array}{l}0.04 \\
(0.14)\end{array}$ & $\begin{array}{l}0.04 \\
(0.11)\end{array}$ \\
\hline Pop 65+ & & & & & $\begin{array}{l}-0.67 \\
(0.57)\end{array}$ & & & \\
\hline Pub. health share & $\begin{array}{l}0.04 \\
(0.19)\end{array}$ & & & & $\begin{array}{l}0.07 \\
(0.19)\end{array}$ & $\begin{array}{l}-0.13^{* * *} \\
(0.04)\end{array}$ & $\begin{array}{l}0.06 \\
(0.16)\end{array}$ & $\begin{array}{l}0.05 \\
(0.18)\end{array}$ \\
\hline Election & & $\begin{array}{l}0.003 \\
(0.006)\end{array}$ & $\begin{array}{l}-0.003 \\
(0.005)\end{array}$ & $\begin{array}{l}-0.003 \\
(0.004)\end{array}$ & $\begin{array}{l}0.002 \\
(0.005)\end{array}$ & $\begin{array}{l}0.002 \\
(0.006)\end{array}$ & $\begin{array}{l}0.002 \\
(0.004)\end{array}$ & $\begin{array}{l}0.001 \\
(0.005)\end{array}$ \\
\hline Ideology & & $\begin{array}{l}-0.006 \\
(0.005)\end{array}$ & $\begin{array}{l}-0.006 \\
(0.006)\end{array}$ & $\begin{array}{l}-0.006 \\
(0.005)\end{array}$ & $\begin{array}{l}-0.003 \\
(0.01)\end{array}$ & $\begin{array}{l}-0.003 \\
(0.006)\end{array}$ & $\begin{array}{l}-0.004 \\
(0.007)\end{array}$ & $\begin{array}{l}-0.004 \\
(0.006)\end{array}$ \\
\hline Coalition_2_3 & & $\begin{array}{l}-0.01 \\
(0.01)\end{array}$ & $\begin{array}{l}0.01 \\
(0.01)\end{array}$ & $\begin{array}{l}-0.008 \\
(0.02)\end{array}$ & $\begin{array}{l}0.01 \\
(0.02)\end{array}$ & $\begin{array}{l}-0.007 \\
(0.02)\end{array}$ & $\begin{array}{l}0.02 \\
(0.02)\end{array}$ & $\begin{array}{l}0.006 \\
(0.02)\end{array}$ \\
\hline Coalition_4 & & $\begin{array}{l}-0.03 \\
(0.02)\end{array}$ & $\begin{array}{l}-0.01 \\
(0.04)\end{array}$ & $\begin{array}{l}-0.03 \\
(0.03)\end{array}$ & $\begin{array}{l}-0.02 \\
(0.04)\end{array}$ & $\begin{array}{l}-0.02 \\
(0.02)\end{array}$ & $\begin{array}{l}-0.007 \\
(0.03)\end{array}$ & $\begin{array}{l}-0.02 \\
(0.03)\end{array}$ \\
\hline Minority gov. & & $\begin{array}{l}-0.01 \\
(0.03)\end{array}$ & $\begin{array}{l}0.01 \\
(0.03)\end{array}$ & $\begin{array}{l}0.0004 \\
(0.03)\end{array}$ & $\begin{array}{l}0.01 \\
(0.02)\end{array}$ & $\begin{array}{l}-0.008 \\
(0.02)\end{array}$ & $\begin{array}{l}0.01 \\
(0.03)\end{array}$ & $\begin{array}{l}0.004 \\
(0.03)\end{array}$ \\
\hline Year fixed eff. & Yes & Yes & Yes & Yes & Yes & Yes & Yes & Yes \\
\hline Country-spec. time trend & Yes & Yes & Yes & Yes & Yes & Yes & Yes & Yes \\
\hline Auxiliary reg. test $(p \text {-value })^{a}$ & 0.00 & 0.05 & 0.01 & 0.00 & 0.00 & 0.00 & 0.00 & 0.00 \\
\hline Observations & 395 & 504 & 451 & 440 & 395 & 443 & 406 & 395 \\
\hline$R$-squared (overall) & 0.38 & 0.85 & 0.06 & 0.53 & 0.36 & 0.69 & 0.06 & 0.34 \\
\hline Number of countries & 21 & 21 & 21 & 21 & 21 & 21 & 21 & 21 \\
\hline
\end{tabular}

a Standard errors in parentheses, ${ }^{* * *}$ significant at $1 \%,{ }^{* *}$ at $5 \%$ and ${ }^{*}$ at $10 \%$ level.

${ }^{b}$ This row presents the $p$-value of the auxiliary regression test. 
Table 5: Regression results with country-specific time trend: dynamic model ${ }^{a}$

\begin{tabular}{|c|c|c|c|c|c|c|c|c|}
\hline & (i) & (ii) & (iii) & (iv) & $(\mathrm{v})$ & (vi) & (vii) & (viii) \\
\hline Lag. heal. expend. & $\begin{array}{l}0.54^{* * *} \\
(0.14)\end{array}$ & $\begin{array}{l}0.70^{* * *} \\
(0.06)\end{array}$ & $\begin{array}{l}0.82^{* * *} \\
(0.17)\end{array}$ & $\begin{array}{l}0.79^{* * *} \\
(0.17)\end{array}$ & $\begin{array}{l}0.44^{* *} \\
(0.17)\end{array}$ & $\begin{array}{l}0.45^{* * *} \\
(0.07)\end{array}$ & $\begin{array}{l}0.91^{* * *} \\
(0.10)\end{array}$ & $\begin{array}{l}0.50^{* * *} \\
(0.14)\end{array}$ \\
\hline GDP & $\begin{array}{l}0.11 \\
(0.11)\end{array}$ & $\begin{array}{l}0.41^{* * *} \\
(0.10)\end{array}$ & $\begin{array}{l}0.43^{* * *} \\
(0.11)\end{array}$ & $\begin{array}{l}0.34^{* * *} \\
(0.11)\end{array}$ & $\begin{array}{l}0.14 \\
(0.10)\end{array}$ & $\begin{array}{l}0.26^{* * *} \\
(0.08)\end{array}$ & $\begin{array}{l}0.47^{* * *} \\
(0.12)\end{array}$ & $\begin{array}{l}0.11 \\
(0.11)\end{array}$ \\
\hline Public pension & $\begin{array}{l}0.13^{* * *} \\
(0.05)\end{array}$ & $\begin{array}{l}0.13^{* * *} \\
(0.05)\end{array}$ & & $\begin{array}{l}0.18^{* * *} \\
(0.05)\end{array}$ & $\begin{array}{l}0.15^{* * *} \\
(0.04)\end{array}$ & $\begin{array}{l}0.13^{* * *} \\
(0.04)\end{array}$ & & $\begin{array}{l}0.14^{* * *} \\
(0.05)\end{array}$ \\
\hline Avg. hours worked & $\begin{array}{l}0.19^{*} \\
(0.10)\end{array}$ & & $\begin{array}{l}-0.02 \\
(0.11)\end{array}$ & $\begin{array}{l}0.04 \\
(0.11)\end{array}$ & $\begin{array}{l}0.20^{* *} \\
(0.09)\end{array}$ & & $\begin{array}{l}-0.08 \\
(0.11)\end{array}$ & $\begin{array}{l}0.21^{* *} \\
(0.10)\end{array}$ \\
\hline Pop 65-69 & $\begin{array}{l}0.02 \\
(0.06)\end{array}$ & & & & & $\begin{array}{l}-0.03 \\
(0.05)\end{array}$ & $\begin{array}{l}-0.12 \\
(0.07)\end{array}$ & $\begin{array}{l}0.02 \\
(0.06)\end{array}$ \\
\hline Pop 70-74 & $\begin{array}{l}-0.02 \\
(0.10)\end{array}$ & & & & & $\begin{array}{l}-0.05 \\
(0.05)\end{array}$ & $\begin{array}{l}-0.007 \\
(0.09)\end{array}$ & $\begin{array}{l}-0.03 \\
(0.10)\end{array}$ \\
\hline Pop 75-79 & $\begin{array}{l}0.05 \\
(0.07)\end{array}$ & & & & & $\begin{array}{l}-0.08^{* * *} \\
(0.03)\end{array}$ & $\begin{array}{l}-0.09^{* *} \\
() .05)\end{array}$ & $\begin{array}{l}0.05 \\
(0.07)\end{array}$ \\
\hline Pop 80-84 & $\begin{array}{l}0.10 \\
(0.07)\end{array}$ & & & & & $\begin{array}{l}-0.06^{* *} \\
(0.03)\end{array}$ & $\begin{array}{l}-0.003 \\
(0.03)\end{array}$ & $\begin{array}{l}0.09 \\
(0.07)\end{array}$ \\
\hline Pop $85+$ & $\begin{array}{l}0.28^{* * *} \\
(0.10)\end{array}$ & & & & & $\begin{array}{l}0.11^{*} \\
(0.06)\end{array}$ & $\begin{array}{l}0.17^{*} \\
(0.09)\end{array}$ & $\begin{array}{l}0.29^{* * *} \\
(0.10)\end{array}$ \\
\hline Pop $65+$ & & & & & $\begin{array}{l}0.47^{*} \\
(0.25)\end{array}$ & & & \\
\hline Pub. health share & $\begin{array}{l}0.05 \\
(0.07)\end{array}$ & & & & $\begin{array}{l}0.04 \\
(0.07)\end{array}$ & $\begin{array}{l}0.06 \\
(0.06)\end{array}$ & $\begin{array}{l}0.003 \\
(0.08)\end{array}$ & $\begin{array}{l}0.04 \\
(0.07)\end{array}$ \\
\hline Election & & $\begin{array}{l}0.008 \\
(0.006)\end{array}$ & $\begin{array}{l}0.005 \\
(0.005)\end{array}$ & $\begin{array}{l}0.004 \\
(0.005)\end{array}$ & $\begin{array}{l}0.005 \\
(0.005)\end{array}$ & $\begin{array}{l}0.006 \\
(0.005)\end{array}$ & $\begin{array}{l}0.009^{*} \\
(0.006)\end{array}$ & $\begin{array}{l}0.005 \\
(0.005)\end{array}$ \\
\hline Ideology & & $\begin{array}{l}-0.003 \\
(0.004)\end{array}$ & $\begin{array}{l}-0.003 \\
(0.003)\end{array}$ & $\begin{array}{c}-0.001 \\
(0.003)\end{array}$ & $\begin{array}{l}0.001 \\
(0.003)\end{array}$ & $\begin{array}{c}-0.002 \\
(0.003)\end{array}$ & $\begin{array}{l}-0.00004 \\
(0.004)\end{array}$ & $\begin{array}{l}0.0003 \\
(0.003)\end{array}$ \\
\hline Coalition_2_3 & & $\begin{array}{l}-0.02 \\
(0.01)\end{array}$ & $\begin{array}{l}0.006 \\
(0.01)\end{array}$ & $\begin{array}{l}-0.004 \\
(0.01)\end{array}$ & $\begin{array}{l}-0.0007 \\
(0.01)\end{array}$ & $\begin{array}{l}-0.01 \\
(0.01)\end{array}$ & $\begin{array}{l}0.01 \\
(0.01)\end{array}$ & $\begin{array}{l}-0.003 \\
(0.01)\end{array}$ \\
\hline Coalition_4 & & $\begin{array}{l}-0.001 \\
(0.02)\end{array}$ & $\begin{array}{l}0.02 \\
(0.02)\end{array}$ & $\begin{array}{l}0.02 \\
(0.02)\end{array}$ & $\begin{array}{l}0.003 \\
(0.02)\end{array}$ & $\begin{array}{l}-0.01 \\
(0.01)\end{array}$ & $\begin{array}{l}0.02 \\
(0.02)\end{array}$ & $\begin{array}{l}0.005 \\
(0.02)\end{array}$ \\
\hline Minority government & & $\begin{array}{l}0.005 \\
(0.01)\end{array}$ & $\begin{array}{l}0.005 \\
(0.009)\end{array}$ & $\begin{array}{l}-0.0003 \\
(0.01)\end{array}$ & $\begin{array}{l}-0.008 \\
(0.01)\end{array}$ & $\begin{array}{c}-0.009 \\
(0.008)\end{array}$ & $\begin{array}{c}-0.003 \\
(0.009)\end{array}$ & $\begin{array}{l}-0.009 \\
(0.008)\end{array}$ \\
\hline Instruments (lagged $\mathrm{H})^{b}$ & 3 & 2 & 6 & 4 & 3 & $3 \& 4$ & 2 & 3 \\
\hline Sargan test (p-value) & 0.15 & 0.00 & 0.31 & 0.05 & 0.08 & 0.05 & 0.04 & 0.07 \\
\hline Country-spec. time trend & Yes & Yes & Yes & Yes & Yes & Yes & Yes & Yes \\
\hline Observations & 393 & 504 & 451 & 440 & 393 & 441 & 404 & 393 \\
\hline Number of countries ${ }^{c}$ & 20 & 21 & 21 & 21 & 20 & 20 & 20 & 20 \\
\hline
\end{tabular}

${ }^{a}$ Standard errors in parentheses, ${ }^{* * *}$ significant at $1 \%,{ }^{* *}$ at $5 \%$ and ${ }^{*}$ at $10 \%$ level.

${ }^{b}$ The number of lagged dependent variable chosen for insturments. For example, specification (viii) uses three periods' lagged $H$, i.e., $\log H_{i, t-2}, \log H_{i, t-3}$ and $\log H_{i, t-4}$ as instruments for $\left(\log H_{i, t-1}-\log H_{i, t-2}\right)$.

${ }^{c}$ New Zealand has two years' data of population (Year 2004 and 2005), which cannot be used for estimations in (i), (v), (vi), (vii) and (viii). 
Table 6: Regression results of the static model: two periods (fixed effects) ${ }^{a}$

\begin{tabular}{|c|c|c|c|c|c|c|c|c|}
\hline "Panel I: 1980-1991 & (i) & (ii) & 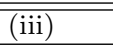 & (iv) & $\overline{(\mathrm{v})}$ & (vi) & (vii) & (viii) \\
\hline GDP & $\begin{array}{l}0.23 \\
(0.34)\end{array}$ & $\begin{array}{l}0.26 \\
(0.28)\end{array}$ & $\begin{array}{l}0.30 \\
(0.40)\end{array}$ & $\begin{array}{l}0.15 \\
(0.35)\end{array}$ & $\begin{array}{l}0.10 \\
(0.33)\end{array}$ & $\begin{array}{l}0.42 \\
(0.33)\end{array}$ & $\begin{array}{l}0.05 \\
(0.41)\end{array}$ & $\begin{array}{l}0.11 \\
(0.38)\end{array}$ \\
\hline Public pension & $\begin{array}{l}0.24^{* *} \\
(0.09)\end{array}$ & $\begin{array}{l}0.28^{* * *} \\
(0.09)\end{array}$ & & $\begin{array}{l}0.24^{* *} \\
(0.11)\end{array}$ & $\begin{array}{l}0.17 \\
(0.11)\end{array}$ & $\begin{array}{l}0.30^{* *} \\
(0.11)\end{array}$ & & $\begin{array}{l}0.20^{*} \\
(0.10)\end{array}$ \\
\hline Avg. hours worked & $\begin{array}{l}0.42 \\
(0.25)\end{array}$ & & $\begin{array}{l}0.09 \\
(0.27)\end{array}$ & $\begin{array}{l}0.16 \\
(0.26)\end{array}$ & $\begin{array}{l}0.34 \\
(0.23)\end{array}$ & & $\begin{array}{l}0.33 \\
(0.22)\end{array}$ & $\begin{array}{l}0.36 \\
(0.22)\end{array}$ \\
\hline Pop 65-69 & $\begin{array}{l}0.37 \\
(0.25)\end{array}$ & & & & & $\begin{array}{l}0.36^{*} \\
(0.19)\end{array}$ & $\begin{array}{l}0.31 \\
(0.26)\end{array}$ & $\begin{array}{l}0.31 \\
(0.25)\end{array}$ \\
\hline Pop 70-74 & $\begin{array}{l}0.29 \\
(0.33)\end{array}$ & & & & & $\begin{array}{l}0.03 \\
(0.18)\end{array}$ & $\begin{array}{l}0.49 \\
(0.32)\end{array}$ & $\begin{array}{l}0.34 \\
(0.35)\end{array}$ \\
\hline Pop 75-79 & $\begin{array}{l}-0.25 \\
(0.22)\end{array}$ & & & & & $\begin{array}{l}-0.36^{*} \\
(0.19)\end{array}$ & $\begin{array}{l}-0.35 \\
(0.25)\end{array}$ & $\begin{array}{l}-0.30 \\
(0.26)\end{array}$ \\
\hline Pop 80-84 & $\begin{array}{l}0.58 \\
(0.46)\end{array}$ & & & & & $\begin{array}{l}0.72^{* *} \\
(0.34)\end{array}$ & $\begin{array}{l}0.49 \\
(0.44)\end{array}$ & $\begin{array}{l}0.57 \\
(0.51)\end{array}$ \\
\hline Pop $85+$ & $\begin{array}{l}-0.26 \\
(0.59)\end{array}$ & & & & & $\begin{array}{l}-0.43 \\
(0.47)\end{array}$ & $\begin{array}{l}0.13 \\
(0.56)\end{array}$ & $\begin{array}{l}-0.15 \\
(0.59)\end{array}$ \\
\hline Pop 65+ & & & & & $\begin{array}{l}1.07 \\
(0.70)\end{array}$ & & & \\
\hline Pub. health share & $\begin{array}{l}0.24 \\
(0.27)\end{array}$ & & & & $\begin{array}{l}0.32 \\
(0.23)\end{array}$ & $\begin{array}{l}-0.05 \\
(0.05)\end{array}$ & $\begin{array}{l}0.39 \\
(0.25)\end{array}$ & $\begin{array}{l}0.35 \\
(0.25)\end{array}$ \\
\hline Election & & $\begin{array}{l}0.0005 \\
(0.01)\end{array}$ & $\begin{array}{l}-0.001 \\
(0.01)\end{array}$ & $\begin{array}{l}-0.009 \\
(0.01)\end{array}$ & $\begin{array}{l}-0.01 \\
(0.01)\end{array}$ & $\begin{array}{l}-0.01 \\
(0.01)\end{array}$ & $\begin{array}{l}-0.009 \\
(0.01)\end{array}$ & $\begin{array}{l}-0.02 \\
(0.01)\end{array}$ \\
\hline Ideology & & $\begin{array}{c}-0.004 \\
(0.01)\end{array}$ & $\begin{array}{l}-0.006 \\
(0.01)\end{array}$ & $\begin{array}{l}-0.007 \\
(0.01)\end{array}$ & $\begin{array}{l}-0.003 \\
(0.01)\end{array}$ & $\begin{array}{l}-0.01 \\
(0.01)\end{array}$ & $\begin{array}{l}-0.005 \\
(0.01)\end{array}$ & $\begin{array}{l}-0.004 \\
(0.01)\end{array}$ \\
\hline Coalition_2_3 & & $\begin{array}{l}-0.02 \\
(0.02)\end{array}$ & $\begin{array}{l}0.04 \\
(0.03)\end{array}$ & $\begin{array}{l}0.04 \\
(0.03)\end{array}$ & $\begin{array}{l}0.05 \\
(0.03)\end{array}$ & $\begin{array}{l}-0.03 \\
(0.02)\end{array}$ & $\begin{array}{l}0.05 \\
(0.03)\end{array}$ & $\begin{array}{l}0.04 \\
(0.04)\end{array}$ \\
\hline Coalition_4 & & $\begin{array}{l}0.04 \\
(0.03)\end{array}$ & $\begin{array}{l}0.13^{* * *} \\
(0.04)\end{array}$ & $\begin{array}{l}0.12^{* * *} \\
(0.04)\end{array}$ & $\begin{array}{l}0.10^{*} \\
(0.05)\end{array}$ & $\begin{array}{l}0.005 \\
(0.02)\end{array}$ & $\begin{array}{l}0.10^{* *} \\
(0.04)\end{array}$ & $\begin{array}{l}0.09^{*} \\
(0.05)\end{array}$ \\
\hline Minority government & & $\begin{array}{l}-0.04 \\
(0.03)\end{array}$ & $\begin{array}{l}-0.01 \\
(0.03)\end{array}$ & $\begin{array}{l}-0.01 \\
(0.03)\end{array}$ & $\begin{array}{l}0.02 \\
(0.02)\end{array}$ & $\begin{array}{l}-0.02 \\
(0.04)\end{array}$ & $\begin{array}{l}0.04 \\
(0.02)\end{array}$ & $\begin{array}{l}0.03 \\
(0.02)\end{array}$ \\
\hline Year fixed effects included & Yes & Yes & Yes & Yes & Yes & Yes & Yes & Yes \\
\hline Auxiliary reg. test (p-value) $)^{b}$ & 0.00 & 0.47 & 0.86 & 0.26 & 0.00 & 0.00 & 0.00 & 0.00 \\
\hline Observations & 137 & 215 & 160 & 154 & 137 & 182 & 143 & 137 \\
\hline R-squared (overall) & 0.52 & 0.8645 & 0.4073 & 0.6085 & 0.38 & 0.8761 & 0.267 & 0.38 \\
\hline Number of countries & 17 & 21 & 19 & 19 & 17 & 19 & 17 & 17 \\
\hline Panel II: 1992-2005 & (i) & (ii) & (iii) & (iv) & $(\mathrm{v})$ & (vi) & (vii) & (viii) \\
\hline GDP & $\begin{array}{l}0.55^{* * *} \\
(0.13)\end{array}$ & $\begin{array}{l}0.78^{* * *} \\
(0.10)\end{array}$ & $\begin{array}{l}0.88 \\
(0.10)\end{array}$ & $\begin{array}{l}0.82^{* * *} \\
(0.10)\end{array}$ & $\begin{array}{l}0.58^{* * *} \\
(0.11)\end{array}$ & $\begin{array}{l}0.66^{* * *} \\
(0.08)\end{array}$ & $\begin{array}{l}0.72^{* * *} \\
(0.10)\end{array}$ & $\begin{array}{l}0.58^{* * *} \\
(0.11)\end{array}$ \\
\hline Public pension & $\begin{array}{l}0.34^{* *} \\
(0.13)\end{array}$ & $\begin{array}{l}0.37^{* * *} \\
(0.13)\end{array}$ & & $\begin{array}{l}0.35^{* *} \\
(0.13)\end{array}$ & $\begin{array}{l}0.32^{* *} \\
(0.13)\end{array}$ & $\begin{array}{l}0.26^{* *} \\
(0.12)\end{array}$ & & $\begin{array}{l}0.31^{* * *} \\
(0.13)\end{array}$ \\
\hline Avg. hours worked & $\begin{array}{l}0.28 \\
-0.22\end{array}$ & & $\begin{array}{l}-0.89^{*} \\
(0.48)\end{array}$ & $\begin{array}{l}-0.14 \\
(0.22)\end{array}$ & $\begin{array}{l}0.33 \\
(0.19)\end{array}$ & & $\begin{array}{l}-0.08 \\
(0.19)\end{array}$ & $\begin{array}{l}0.27 \\
(0.20)\end{array}$ \\
\hline Pop 65-69 & $\begin{array}{l}-0.31^{* *} \\
(0.11)\end{array}$ & & & & & $\begin{array}{l}-0.30^{* * *} \\
(0.10)\end{array}$ & $\begin{array}{l}-0.19^{*} \\
(0.11)\end{array}$ & $\begin{array}{l}-0.29^{* *} \\
(0.11)\end{array}$ \\
\hline Pop 70-74 & $\begin{array}{l}-0.11 \\
(0.14)\end{array}$ & & & & & $\begin{array}{l}-0.08 \\
(0.14)\end{array}$ & $\begin{array}{l}-0.05 \\
(0.14)\end{array}$ & $\begin{array}{l}-0.15 \\
(0.15)\end{array}$ \\
\hline Pop 75-79 & $\begin{array}{l}-0.14^{* *} \\
(0.05)\end{array}$ & & & & & $\begin{array}{l}-0.13^{* *} \\
(0.05)\end{array}$ & $\begin{array}{l}-0.08^{*} \\
(0.05)\end{array}$ & $\begin{array}{l}-0.13^{* * *} \\
(0.04)\end{array}$ \\
\hline Pop 80-84 & $\begin{array}{l}-0.12 \\
(0.08)\end{array}$ & & & & & $\begin{array}{l}-0.10 \\
(0.08)\end{array}$ & $\begin{array}{l}-0.10 \\
(0.10)\end{array}$ & $\begin{array}{l}-0.13 \\
(0.08)\end{array}$ \\
\hline Pop $85+$ & $\begin{array}{l}0.07 \\
(0.13)\end{array}$ & & & & & $\begin{array}{l}0.09 \\
(0.13)\end{array}$ & $\begin{array}{l}0.13 \\
(0.17)\end{array}$ & $\begin{array}{l}0.05 \\
(0.14)\end{array}$ \\
\hline Pop 65+ & & & & & $\begin{array}{l}-0.71 \text { *** } \\
(0.24)\end{array}$ & & & \\
\hline Pub. health share & $\begin{array}{l}0.20 \\
(0.18)\end{array}$ & & & & $\begin{array}{l}0.20 \\
(0.16)\end{array}$ & $\begin{array}{l}0.16 \\
(0.18)\end{array}$ & $\begin{array}{l}0.31 \\
(0.23)\end{array}$ & $\begin{array}{l}0.18 \\
(0.18)\end{array}$ \\
\hline Election & & $\begin{array}{l}0.003 \\
(0.01)\end{array}$ & $\begin{array}{c}-0.003 \\
(0.01)\end{array}$ & $\begin{array}{l}0.001 \\
(0.01)\end{array}$ & $\begin{array}{l}0.008 \\
-0.005\end{array}$ & $\begin{array}{l}0.007 \\
(0.01)\end{array}$ & $\begin{array}{l}0.005 \\
(0.01)\end{array}$ & $\begin{array}{l}0.007 \\
(0.01)\end{array}$ \\
\hline Ideology & & $\begin{array}{l}-0.001 \\
(0.01)\end{array}$ & $\begin{array}{l}-0.01 \\
(0.01)\end{array}$ & $\begin{array}{l}-0.001 \\
(0.01)\end{array}$ & $\begin{array}{l}0.004 \\
(0.01)\end{array}$ & $\begin{array}{l}0.005 \\
(0.01)\end{array}$ & $\begin{array}{l}0.005 \\
(0.01)\end{array}$ & $\begin{array}{l}0.005 \\
(0.01)\end{array}$ \\
\hline Coalition ( 2 or 3 parties) & & $\begin{array}{l}0.04 \\
(0.02)\end{array}$ & $\begin{array}{l}0.02 \\
(0.02)\end{array}$ & $\begin{array}{l}0.04 \\
(0.02)\end{array}$ & $\begin{array}{l}0.05^{* *} \\
(0.02)\end{array}$ & $\begin{array}{l}0.04^{* *} \\
(0.02)\end{array}$ & $\begin{array}{l}0.06^{* * * *} \\
(0.01)\end{array}$ & $\begin{array}{l}0.04^{* *} \\
(0.02)\end{array}$ \\
\hline Coalition ( 4 or more parties) & & $\begin{array}{l}0.03 \\
(0.04)\end{array}$ & $\begin{array}{l}0.04 \\
(0.03)\end{array}$ & $\begin{array}{l}0.03 \\
(0.03)\end{array}$ & $\begin{array}{l}0.06^{* * *} \\
(0.02)\end{array}$ & $\begin{array}{l}0.06^{* * * *} \\
(0.02)\end{array}$ & $\begin{array}{l}0.08 * * * \\
(0.02)\end{array}$ & $\begin{array}{l}0.06 * * * \\
(0.02)\end{array}$ \\
\hline Minority government & & $\begin{array}{l}-0.004 \\
(0.02)\end{array}$ & $\begin{array}{l}-0.02 \\
(0.03)\end{array}$ & $\begin{array}{l}-0.006 \\
(0.02)\end{array}$ & $\begin{array}{l}-0.004 \\
(0.02)\end{array}$ & $\begin{array}{l}-0.01 \\
(0.02)\end{array}$ & $\begin{array}{l}-0.01 \\
(0.02)\end{array}$ & $\begin{array}{l}-0.008 \\
(0.02)\end{array}$ \\
\hline Year fixed effects included & Yes & Yes & Yes & Yes & Yes & Yes & Yes & Yes \\
\hline Auxiliary reg. test (p-value) $)^{b}$ & 0.00 & 0.00 & 0.00 & 0.01 & 0.01 & 0.00 & 0.00 & 0.00 \\
\hline Observations & 258 & 289 & 291 & 286 & 258 & 261 & 263 & 258 \\
\hline R-squared (overall) & 0.75 & 0.89 & 0.70 & 0.88 & 0.80 & 0.75 & 0.56 & 0.74 \\
\hline Number of countries & 21 & 21 & 21 & 21 & 21 & 21 & 21 & 21 \\
\hline
\end{tabular}

${ }^{a}$ Standard errors in parentheses, ${ }^{* * *}$ significant at $1 \%,{ }^{* *}$ at $5 \%$ and ${ }^{*}$ at $10 \%$ level. ${ }^{b} p$-value of the auxiliary regression test. 
Table 7: Regression results of the dynamic model: two periods

\begin{tabular}{|c|c|c|c|c|c|c|c|c|}
\hline Panel I: 1980-1991 & (i) & (ii) & (iii) & (iv) & (v) & (vi) & (vii) & (viii) \\
\hline Lagged health expend. & $\begin{array}{l}0.06 \\
(0.28)\end{array}$ & $\begin{array}{l}0.45^{* * *} \\
(0.10)\end{array}$ & $\begin{array}{l}0.48^{* * *} \\
(0.15)\end{array}$ & $\begin{array}{l}0.45^{* * *} \\
(0.17)\end{array}$ & $\begin{array}{l}0.07 \\
(0.29)\end{array}$ & $\begin{array}{l}0.22^{* *} \\
(0.11)\end{array}$ & $\begin{array}{l}-0.1 \\
(0.28)\end{array}$ & $\begin{array}{l}0.05 \\
(0.29)\end{array}$ \\
\hline GDP & $\begin{array}{l}-0.06 \\
(0.16)\end{array}$ & $\begin{array}{l}0.57 * * * \\
(0.16)\end{array}$ & $\begin{array}{l}0.57^{* * *} \\
(0.12)\end{array}$ & $\begin{array}{l}0.47^{* * *} \\
(0.12)\end{array}$ & $\begin{array}{l}0.22^{*} \\
(0.13)\end{array}$ & $\begin{array}{l}0.18 \\
(0.13)\end{array}$ & $\begin{array}{l}-0.05 \\
(0.16)\end{array}$ & $\begin{array}{l}-0.07 \\
(0.16)\end{array}$ \\
\hline Public pension & $\begin{array}{l}0.13^{* *} \\
(0.06)\end{array}$ & $\begin{array}{l}0.15^{* *} \\
(0.06)\end{array}$ & & $\begin{array}{l}0.12^{* *} \\
(0.06)\end{array}$ & $\begin{array}{l}0.13^{* *} \\
(0.06)\end{array}$ & $\begin{array}{l}0.11^{*} \\
(0.06)\end{array}$ & & $\begin{array}{l}0.14^{* *} \\
(0.06)\end{array}$ \\
\hline Avg. hours worked & $\begin{array}{l}0.36^{* *} \\
(0.17)\end{array}$ & & $\begin{array}{l}-0.15 \\
(0.11)\end{array}$ & $\begin{array}{l}-0.1 \\
(0.11)\end{array}$ & $\begin{array}{l}0.24 \\
(0.16)\end{array}$ & & $\begin{array}{l}0.35^{* *} \\
(0.16)\end{array}$ & $\begin{array}{l}0.37^{* *} \\
(0.18)\end{array}$ \\
\hline Pop 65-69 & $\begin{array}{l}0.45^{* *} \\
(0.18)\end{array}$ & & & & & $\begin{array}{l}0.33^{* * *} \\
(0.09)\end{array}$ & $\begin{array}{l}0.48^{* * *} \\
(0.19)\end{array}$ & $\begin{array}{l}0.45^{* *} \\
(0.18)\end{array}$ \\
\hline Pop 70-74 & $\begin{array}{l}0.04 \\
(0.18)\end{array}$ & & & & & $\begin{array}{l}0.29 * * * \\
(0.08)\end{array}$ & $\begin{array}{l}0.25 \\
(0.19)\end{array}$ & $\begin{array}{l}0.04 \\
(0.18)\end{array}$ \\
\hline Pop 75-79 & $\begin{array}{l}-0.11 \\
(0.12)\end{array}$ & & & & & $\begin{array}{l}-0.01 \\
(0.12)\end{array}$ & $\begin{array}{l}-0.07 \\
(0.13)\end{array}$ & $\begin{array}{l}-0.09 \\
(0.13)\end{array}$ \\
\hline Pop 80-84 & $\begin{array}{l}0.10 \\
(0.20)\end{array}$ & & & & & $\begin{array}{l}-0.06 \\
(0.22)\end{array}$ & $\begin{array}{l}-0.07 \\
(0.22)\end{array}$ & $\begin{array}{l}0.05 \\
(0.22)\end{array}$ \\
\hline Pop 85+ & $\begin{array}{l}0.03 \\
(0.15)\end{array}$ & & & & & $\begin{array}{l}0.14 \\
(0.15)\end{array}$ & $\begin{array}{l}0.24^{*} \\
(0.14)\end{array}$ & $\begin{array}{l}0.06 \\
(0.15)\end{array}$ \\
\hline Pop $65+$ & & & & & $\begin{array}{l}0.94^{* *} \\
(0.38)\end{array}$ & & & \\
\hline Pub. health share & $\begin{array}{l}0.06 \\
(0.10)\end{array}$ & & & & $\begin{array}{l}0.04 \\
(0.11)\end{array}$ & $\begin{array}{l}0.01 \\
(0.07)\end{array}$ & $\begin{array}{l}0.05 \\
(0.11)\end{array}$ & $\begin{array}{l}0.06 \\
(0.10)\end{array}$ \\
\hline Election & & $\begin{array}{l}0.009 \\
(0.01)\end{array}$ & $\begin{array}{l}0.004 \\
(0.01)\end{array}$ & $\begin{array}{l}0.003 \\
(0.01)\end{array}$ & $\begin{array}{l}0.005 \\
(0.01)\end{array}$ & $\begin{array}{l}0.003 \\
(0.01)\end{array}$ & $\begin{array}{l}0.005 \\
(0.01)\end{array}$ & $\begin{array}{l}0.005 \\
(0.01)\end{array}$ \\
\hline Ideology & & $\begin{array}{l}-0.004 \\
(0.01)\end{array}$ & $\begin{array}{l}0.0001 \\
(0.004)\end{array}$ & $\begin{array}{l}-0.001 \\
(0.01)\end{array}$ & $\begin{array}{l}-0.003 \\
(0.01)\end{array}$ & $\begin{array}{l}-0.004 \\
(0.01)\end{array}$ & $\begin{array}{l}0.003 \\
(0.01)\end{array}$ & $\begin{array}{l}-0.0001 \\
(0.01)\end{array}$ \\
\hline Coalition ( 2 or 3 parties) & & $\begin{array}{l}-0.02 \\
(0.02)\end{array}$ & $\begin{array}{l}0.009 \\
(0.01)\end{array}$ & $\begin{array}{l}-0.006 \\
(0.01)\end{array}$ & $\begin{array}{l}-0.003 \\
(0.02)\end{array}$ & $\begin{array}{l}-0.01 \\
(0.01)\end{array}$ & $\begin{array}{l}0.01 \\
(0.01)\end{array}$ & $\begin{array}{l}-0.0001 \\
(0.02)\end{array}$ \\
\hline Coalition ( 4 or more parties) & & $\begin{array}{l}0.01 \\
(0.04)\end{array}$ & $\begin{array}{l}0.02 \\
(0.03)\end{array}$ & $\begin{array}{l}0.01 \\
(0.03)\end{array}$ & $\begin{array}{l}-0.01 \\
(0.04)\end{array}$ & $\begin{array}{l}-0.02 \\
(0.03)\end{array}$ & $\begin{array}{l}-0.00005 \\
(0.04)\end{array}$ & $\begin{array}{l}-0.006 \\
(0.04)\end{array}$ \\
\hline Minority government & & $\begin{array}{l}0.02 \\
(0.02)\end{array}$ & $\begin{array}{l}0.02 \\
(0.01)\end{array}$ & $\begin{array}{l}0.03^{* *} \\
(0.01)\end{array}$ & $\begin{array}{l}0.002 \\
(0.02)\end{array}$ & $\begin{array}{l}0.01 \\
(0.02)\end{array}$ & $\begin{array}{l}0.003 \\
(0.01)\end{array}$ & $\begin{array}{l}-0.002 \\
(0.02)\end{array}$ \\
\hline Instruments (lagged H) & 2 & 2 & 2 & 2 & 2 & 3 & 2 & 2 \\
\hline Sargan test ( $p$-value) & 0.02 & 0.00 & 0.31 & 0.37 & 0.07 & 0.15 & 0.06 & 0.01 \\
\hline Observations & 133 & 207 & 156 & 150 & 133 & 174 & 139 & 133 \\
\hline Number of countries & 15 & 19 & 17 & 17 & 15 & 17 & 15 & 15 \\
\hline Panel II: 1992-2005 & (i) & (ii) & (iii) & (iv) & (v) & (vi) & (vii) & (viii) \\
\hline Lagged health expend. & $\begin{array}{l}0.50^{* * *} \\
(0.12)\end{array}$ & $\begin{array}{l}0.87^{* * *} \\
(0.11)\end{array}$ & $\begin{array}{l}0.45^{* * *} \\
(0.11)\end{array}$ & $\begin{array}{l}0.82^{* * *} \\
(0.18)\end{array}$ & $\begin{array}{l}0.56^{* * *} \\
(0.14)\end{array}$ & $\begin{array}{l}0.50^{* * *} \\
(0.13)\end{array}$ & $\begin{array}{l}0.49^{* * *} \\
(0.16)\end{array}$ & $\begin{array}{l}0.51^{* * *} \\
(0.13)\end{array}$ \\
\hline GDP & $\begin{array}{l}0.24^{*} \\
(0.13)\end{array}$ & $\begin{array}{l}0.28^{* *} \\
(0.11)\end{array}$ & $\begin{array}{l}0.49^{* * *} \\
(0.10)\end{array}$ & $\begin{array}{l}0.31^{* *} \\
(0.13)\end{array}$ & $\begin{array}{l}0.31^{* *} \\
(0.14)\end{array}$ & $\begin{array}{l}0.23^{*} \\
(0.12)\end{array}$ & $\begin{array}{l}0.48^{* * *} \\
(0.13)\end{array}$ & $\begin{array}{l}0.24^{*} \\
(0.14)\end{array}$ \\
\hline Public pension & $\begin{array}{l}0.17^{* * *} \\
(0.06)\end{array}$ & $\begin{array}{l}0.25 * * * \\
(0.06)\end{array}$ & & $\begin{array}{l}0.25^{* * * *} \\
(0.06)\end{array}$ & $\begin{array}{l}0.19 * * * \\
(0.07)\end{array}$ & $\begin{array}{l}0.18^{* * *} \\
(0.06)\end{array}$ & & $\begin{array}{l}0.17^{* * *} \\
(0.07)\end{array}$ \\
\hline Avg. hours worked & $\begin{array}{l}-0.04 \\
(0.16)\end{array}$ & & $\begin{array}{c}-0.28^{*} \\
(0.15)\end{array}$ & $\begin{array}{l}-0.06 \\
(0.17)\end{array}$ & $\begin{array}{l}0.02 \\
(0.15)\end{array}$ & & $\begin{array}{c}-0.29^{*} \\
(0.15)\end{array}$ & $\begin{array}{l}-0.04 \\
(0.16)\end{array}$ \\
\hline Pop 65-69 & $\begin{array}{l}-0.13^{*} \\
(0.07)\end{array}$ & & & & & $\begin{array}{c}-0.12^{*} \\
(0.07)\end{array}$ & $\begin{array}{l}-0.15^{* *} \\
(0.07)\end{array}$ & $\begin{array}{l}-0.13^{*} \\
(0.07)\end{array}$ \\
\hline Pop 70-74 & $\begin{array}{l}-0.06 \\
(0.09)\end{array}$ & & & & & $\begin{array}{l}-0.1 \\
(0.10)\end{array}$ & $\begin{array}{l}0.06 \\
(0.09)\end{array}$ & $\begin{array}{l}-0.1 \\
(0.10)\end{array}$ \\
\hline Pop 75-79 & $\begin{array}{l}-0.008 \\
(0.05)\end{array}$ & & & & & $\begin{array}{l}-0.02 \\
(0.05)\end{array}$ & $\begin{array}{l}0.04 \\
(0.05)\end{array}$ & $\begin{array}{l}-0.007 \\
(0.05)\end{array}$ \\
\hline Pop 80-84 & $\begin{array}{l}0.10^{*} \\
(0.05)\end{array}$ & & & & & $\begin{array}{l}0.11^{* *} \\
(0.05)\end{array}$ & $\begin{array}{l}0.10^{*} \\
(0.05)\end{array}$ & $\begin{array}{l}0.11^{* *} \\
(0.05)\end{array}$ \\
\hline Pop $85+$ & $\begin{array}{l}0.34^{* * *} \\
(0.09)\end{array}$ & & & & & $\begin{array}{l}0.37^{* * *} \\
(0.09)\end{array}$ & $\begin{array}{l}0.34^{* * *} \\
(0.08)\end{array}$ & $\begin{array}{l}0.37^{* * *} \\
(0.09)\end{array}$ \\
\hline Pop $65+$ & & & & & $\begin{array}{l}0.10 \\
(0.14)\end{array}$ & & & \\
\hline Pub. health share & $\begin{array}{l}-0.12 \\
(0.11)\end{array}$ & & & & $\begin{array}{l}-0.13 \\
(0.12)\end{array}$ & $\begin{array}{l}-0.12 \\
(0.11)\end{array}$ & $\begin{array}{l}-0.16 \\
(0.10)\end{array}$ & $\begin{array}{l}-0.12 \\
(0.11)\end{array}$ \\
\hline Election & & $\begin{array}{l}0.002 \\
(0.01)\end{array}$ & $\begin{array}{l}0.0004 \\
(0.01)\end{array}$ & $\begin{array}{l}0.001 \\
(0.01)\end{array}$ & $\begin{array}{l}0.003 \\
(0.01)\end{array}$ & $\begin{array}{l}0.002 \\
(0.01)\end{array}$ & $\begin{array}{l}0.006 \\
(0.01)\end{array}$ & $\begin{array}{l}0.002 \\
(0.01)\end{array}$ \\
\hline Ideology & & $\begin{array}{l}0.001 \\
(0.005)\end{array}$ & $\begin{array}{l}-0.0007 \\
(0.004)\end{array}$ & $\begin{array}{l}0.002 \\
(0.005)\end{array}$ & $\begin{array}{l}0.0007 \\
(0.005)\end{array}$ & $\begin{array}{l}0.0006 \\
(0.005)\end{array}$ & $\begin{array}{l}-0.002 \\
(0.005)\end{array}$ & $\begin{array}{l}0.001 \\
(0.005)\end{array}$ \\
\hline Coalition (2 or 3 parties) & & $\begin{array}{l}0.009 \\
(0.02)\end{array}$ & $\begin{array}{l}0.008 \\
(0.01)\end{array}$ & $\begin{array}{l}0.009 \\
(0.02)\end{array}$ & $\begin{array}{l}-0.002 \\
(0.02)\end{array}$ & $\begin{array}{l}-0.006 \\
(0.02)\end{array}$ & $\begin{array}{l}0.0007 \\
(0.01)\end{array}$ & $\begin{array}{l}-0.006 \\
(0.02)\end{array}$ \\
\hline Coalition ( 4 or more parties) & & $\begin{array}{l}0.01 \\
(0.02)\end{array}$ & $\begin{array}{l}0.01 \\
(0.02)\end{array}$ & $\begin{array}{l}0.01 \\
(0.02)\end{array}$ & $\begin{array}{l}0.001 \\
(0.02)\end{array}$ & $\begin{array}{l}0.004 \\
(0.02)\end{array}$ & $\begin{array}{l}0.0005 \\
(0.02)\end{array}$ & $\begin{array}{l}0.005 \\
(0.02)\end{array}$ \\
\hline Minority government & & $\begin{array}{l}-0.01 \\
(0.01)\end{array}$ & $\begin{array}{l}-0.003 \\
(0.01)\end{array}$ & $\begin{array}{l}-0.02 \\
(0.01)\end{array}$ & $\begin{array}{l}-0.01 \\
(0.01)\end{array}$ & $\begin{array}{l}-0.01 \\
(0.01)\end{array}$ & $\begin{array}{l}-0.006 \\
(0.01)\end{array}$ & $\begin{array}{l}-0.01 \\
(0.01)\end{array}$ \\
\hline Instruments (lagged $\mathrm{H}$ ) & 2 & 4 & 5 & 4 & 2 & 2 & 2 & 2 \\
\hline Sargan test (p-value) & 0.49 & 0.03 & 0.17 & 0.03 & 0.52 & 0.38 & 0.38 & 0.41 \\
\hline Observations & 254 & 289 & 291 & 286 & 254 & 257 & 261 & 254 \\
\hline Number of countries & 19 & 21 & 21 & 21 & 19 & 19 & 20 & 19 \\
\hline
\end{tabular}


Table 8: The Averages in Developed OECD Countries from 1980-2005

\begin{tabular}{llll}
\hline \hline & 1980 & 2005 & $\frac{2005}{1980}$ \\
\hline Health expend. per capita & $\$ 1378$ & $\$ 3152$ & 2.3 \\
Health expend. (\% of GDP) & $6.7 \%$ & $9.6 \%$ & 1.4 \\
GDP per capita & $\$ 19738$ & $\$ 33467$ & 1.7 \\
Public pension payments per elderly person & $\$ 1035$ & $\$ 1912$ & 1.9 \\
Avg. hour worked per working-age person & 1126 & 1131 & 1.0 \\
Public health share & $69.7 \%$ & $69.6 \%$ & 1.0 \\
\hline
\end{tabular}

